ACTIVITIES OF THE U. S. GEOLOGICAL SURVEY WATER-RESOURCES

DIVISION IN NORTH CAROLINA, 1986

Open-File Report 86-226

Prepared in cooperation with the

NORTH CAROLINA DEPARTMENT OF NATURAL RESOURCES

AND COMMUNITY DEVELOPMENT

AND OTHER FEDERAL, STATE, AND LOCAL AGENCIES

Raleigh, North Carolina 
UNITED STATES DEPARTMENT OF THE INTERIOR

DONALD PAUL HODEL, Secretary

GEOLOGICAL SURVEY

Dallas L. Peck, Director 


\section{PREFACE}

This report describes water-resources programs conducted by the U. S. Geological Survey in the State of North Carolina during 1985 and proposed programs for 1986 . This is the first in a series of biennial progress reports on Survey activities in the State. The Survey is proud of its reputation as an impartial, fact-finding and researchoriented agency. Survey activities involve such things as gathering, interpreting, and publishing hydrologic data and scientific information in support of State and local water-resources planning, management, and regulatory programs.

The water-resources programs described in the report are funded through cooperative agreements with State and local agencies and through special agreements with other Federal agencies. Cooperative programs provide hydrologic information that is of mutual interest to the Survey, other Federal agencies, and State and local agencies. Cooperative programs are reviewed annually to insure that State, local, and national priorities are being met.

For additional information, write to:

District Chief

U. S. Geological Survey

Post office Box 2857

Raleigh, North Carolina 27602

Telephone: (919) 856-4510
Copies of this report may be purchased from:

U.S. Geological Survey Open-File Services Section Box 25425, Federal Center Denver, Colorado 80225

Telephone: (303) 234-5888 


\section{CONTENTS}

Page

Introduction. . . . . . . . . . . . . . . . . . . . 1

Sources of funds. . . . . . . . . . . . . . . . 5

Cooperating agencies. . . . . . . . . . . . . . . 7

District organization . . . . . . . . . . . . . . . 8

Water-resources conditions. . . . . . . . . . . . . . 12

Water-resources activities. . . . . . . . . . . . . . . . 22

Hydrologic records ....... . . . . . . . . . . . 22

NC 00-001 Streamflow network in North Carolina. . . . . 23

NC 00-002 Ground-water network in North Carolina. . . . . 25

NC 00-003 Water-qual ity network in North Carolina . . .. 27

NC 00-004 Index sediment station--Yadkin River. . . . . . 29

Hydrologic studies .................... 30

NC 00-003 Effects of highway runoff on receiving waters . . 31

NC 83-005 Effects of atmospheric deposition on water qual ity of North Carolina streams. . . . . . . . . 32

NC 00-006 Flood investigations. . . . . . . . . . . 33

NC 00-007 Water-use data collection program in North Carolina................... . . 34

NC 76-053 Effects of channelization on the hydrology of Chicod Creek watershed, North Carolina ...... . . 35

SR 77-056 Appalachian basin waste-storage project... . 36

NC 78-063 Sediment characteristics of streams in North Carolina . . . . . . . . . . . . . 37

NC 79-067 Ground-water development potential in the Piedmont and mountainous areas of North Carolina . . . 39

NC 80-068 Water quality of urban areas in Charlotte and Mecklenburg County, North Carolina .. . . . . . . . 40

NC 80-070 Urban hydrology of the Coastal Plain. . . . . . 42

NC 80-071 Coastal Plain aquifer study (RASA). . . . . . . 43

NC 83-073 Water quality of inflow to Falls and Jordan Lakes, North Carolina. . . . . . . . . . . . . . 44

NC 83-074 Effects of stream restoration on hydrology of the Grove Creek watershed near Kenansville, North Carolina ... . . . . . . . . . . . . . 45

NC 83-075 Central Coastal Plain aquifer study . . . . . . 46

NC 84-076 Effects of land use on stream biology . . . . . . 47

NC 84-077 The effects of land use on ground-water quality in the Piedmont province, North Carolina . . . . . . 4 48

NC 84-078 North Atlantic Coastal Plain hydrology and its relation to disposal of nuclear waste in buried crystalline rocks. . . . . . . . . . . . . . 49

NC 84-079 Modeling of ground-water movement within the combined regolith fractured-rock aquifer system of the central Piedmont province, North Carolina. . . . . 50 
Hydrologic studies

NC 85-081 Effects of 1 and-management practices on sediment and chemical transport in Guilford County, North Carolina ................................

NC 85-082 Evaluation of the hydrology in the Cincinnati Arch region with regard to isolation of nuclear

wastes in buried crystalline rocks....... . 52

Surface water. . . . . . . . . . . . . . . . . 55

Data reports. . . . . . . . . . . . . . . 55

Interpretive reports. . . . . . . . . . . . . . . . 56

Qual ity of water..................... 59

Data reports. . . . . . . . . . . . . . . . 59

Interpretive reports. . . . . . . . . . . . . . 60

Ground water ......................... 62

Data reports. . . . . . . . . . . . . . . . 62

Interpretive reports. . . . . . . . . . . . . . 63

Water-resources reports . . . . . . . . . . . . 68 


\section{ILLUSTRATIONS}

Page

Figure 1. Proportion of funding for major programs conducted

by the North Carolina District in

fiscal year $1985 \ldots . . . . . . . . . .66$

2. Organizational chart for the North Carolina District. 8

3-4. Maps showing:

3. U. S. Geological Survey offices in North Carolina . . 9

4. Selected index stations in the streamflow, ground-water, and water-quality monitoring networks. . . . . . . . . . 13

5-9. Graphs showing:

5. Variation of discharge at selected long-term index stations for the 1985 water year with median discharge for the period 1951-80. . . . . 14

6. Variation of water levels at selected long-term observation wells for the 1985 water year with month-end, high, low, and average levels for the period of records . . . . . . . . 15

7. Declining ground-water levels at Cove City and water-level declines in the Coastal Plain province............. 18

8. Variation of specific conductance at selected long-term stations during the 1985 water year with means for the period 1975-85 . . . . . . 19

9. Variation of total annual suspended-sediment loads and mean water discharges at Yadkin River at Yadk in College, 1980-85 ....... 21

10-12. Maps showing locations of:

10. Streamflow monitoring-network stations - $1985 \ldots 24$

11. Ground-water level monitoring-network stations - 1985. . . . . . . . . . 26

12. Water-quality monitoring-network stations - 1985. . 28 


\title{
ACTIVITIES OF THE U. S. GEOLOGICAL SURVEY WATER-RESOURCES \\ DIVISION IN NORTH CAROLINA, 1986
}

\author{
Compiled and Edited by \\ J. F. Turner, Jr., and Rebecca J. Deckard
}

INTRODUCTION

Effective management of the Nation's water resources requires an understanding of hydrologic systems and the factors that determine the distribution, availability, and quality of water. Within the Federal Government, the U.S. Geological Survey has the principal responsibility for providing hydrologic information and for appraising the Nation's water resources. The water-resources activities of the $U$. S. Geological Survey are diverse, ranging from individual research investigations of specific aspects of the hydrologic cycle to large programs of regional water-resources investigations, such as the Regional Aquifer System Analyses and the operation of nationwide water-data networks.

The Geological Survey provides the hydrologic information needed by others to help manage the Nation's water resources. To accomplish this mission, the Survey cooperates with State and local governments and other Federal agencies in the following activities:

- Collects data on a systematic basis to determine the quantity, quality, and use of surface and ground water, and the quality of precipitation.

- Conducts water-resources investigations and assessments at national, State, and local scales, characterizes water-resources conditions, and provides the capability to predict the impact of managerial actions, proposed development plans, and natural phenomena on the resource.

- Conducts basic and problem-oriented hydrologic and water-related research that is likely to produce knowledge useful for the resolution of waterresources problems facing the States, regions, and Nation.

- Acquires information useful in predicting and delineating water-related natural hazards from flooding, volcanoes, mudflows, and land subsidence.

- Coordinates the activities of all Federal agencies in the acquisition of water data and operates water information centers. 
- Disseminates data and the results of investigations through reports, maps, and other forms of public release.

- Provides scientific and technical assistance in hydrology to other Federal agencies, to State and local agencies, to licensees of the Federal Energy Regulatory Commission, and, on behalf of the U. S. Department of State, to international agencies.

- Administers the provision of the Water Resources Research Act of 1984 which includes the State Water Resources Research Institute Program (Section 104) and the National Water Resources Research Grant Program (Section 105).

Authority for carrying out the Geological Survey's mission derives from legislation of 1879, which established the Geological Survey, and legislation of 1888 and 1894, which authorized the survey of irrigable lands in arid regions and provided funds for gaging streams and determining the water supply of the Nation. Congressional appropriations have been made annually since 1894 for gaging streams and performing other functions relating to water resources. In 1964, the mission was broadened to include the role of lead agency in the coordination of the activities of all Federal agencies in the acquisition of certain water data. This responsibility, assigned to the Department of the Interior by Office of Management and Budget Circular A-67, was delegated to the Geological Survey and its Water Resources Division by the Department. Most recently, the Department of the Interior designated the Geological Survey as the administering agency for Title I of the Water Resources Research Act of 1984.

The Survey coordinates water-data acquisition activities of the Federal Government. Effective coordination has minimized duplication of data-collection activities among Federal agencies, thereby strengthening the national data base and accessibility and use of the data.

The Federal-State Cooperative Program has provided timely water information for all levels of government for many years. The cooperative program has enhanced awareness of State and local water problems and issues and has enhanced transfer and exchange of valuable information. Most studies conducted within the cooperative program address local and State problems; however, results are of national interest and significance because of possible application in other areas of the country. 
The Geological Survey conducts statewide water-resources programs in North Carolina in cooperation with State, local and Federal agencies. These investigations include hydrologic data collection, applied research, and other interpretive studies. These programs are funded through cooperative agreements with the North Carolina Departments of Natural Resources and Community Development, Human Resources, and Transportation, as we11 as more than a dozen city and county governmental agencies. Some indirect support is provided by private enterprise. The Survey also conducts special studies and data-collection programs for the U. S. Army Corps of Engineers, the U. S. Soil Conservation Service, the Tennessee Valley Authority and the U. S. Environmental Protection Agency. A 1 ist of all Survey cooperators in North Carolina can be found on page 7 of this report.

Water-resources programs conducted by the Geological Survey in North Carolina fall into two principal categories, including hydrologic records and hydrologic investigations. The hydrologic records activities include the systematic collection and processing of data from streamflow, ground-water, and water-quality stations. Data for these stations are stored in the National WATSTORE computer files of the Survey located at Reston, Virginia, and are available on request. Data for selected stations are published as part of an annual report entitled, "Water Resources Data, North Carolina," and other formal publications of the Survey.

Hydrologic investigations address a wide range of environmental problems for existing and development-induced conditions. Currently, there are 20 interpretive studies in process. Results of these studies will be published in a variety of scientific and technical reports, abstracts, and papers. Reports are provided to local cooperating agencies and various i ibraries and repositories.

Cooperative programs have provided scientific information and data on the State's water resources for current and future development conditions which have shown that water resources in most areas of North Carolina are abundant. However, drought periods during the past several years have revealed that supplies are not unlimited. Recent controversies regarding eutrophication, synthetic organic chemicals, phosphate detergents, and other stream-quality issues indicate the need for detailed information on the quality of our drinking-water sources. The ability of the State's ground-water system to meet future demands is also largely unknown.

Withdrawals have produced water-level declines of 150 feet and greater for 1 arge areas of the northeast and central Coastal Plain, and the whole question of the potential for ground-water to provide moderate and large supplies in the mountain and Piedmont areas is largely unexplored. 
Some water managers and planners consider interbasin transfer as a means to meet future needs in water-poor areas. The hydrologic consequences of such transfers, including freshwater inflow necessary to maintain viable environmental conditions in estuary systems and the effects of proportionately increased waste loading, may not be adequately known.

Development impacts on water resources are becoming particularly visible in new and expanding urban, industrial, and agricultural areas. Increased flooding potential, deterioration of water quality of streams and ground-water systems from waste disposal, landfill operations, and acid deposition from rainfall are a few examples. In coastal areas, eutrophication of estuary systems from nutrient loading, ecological damage caused by altered patterns of freshwater inflow, declining ground-water levels from overpumping, increased risk for saltwater intrusion, and overdrainage from channelization and dredging projects are of high concern.

Some of the more sensitive hydrologically oriented environmental concerns in North Carolina are as follows:

0 overstressed ground-water systems in the central and northeast Coastal Plain;

- overstressed surface-water supplies in the Blue Ridge and Piedmont provinces;

0 nutrient loading and eutrophication of major estuaries;

- possible ground-water contamination by waste disposal, induced saltwater intrusion, and other contaminants;

- possible trace metals and organic substances in stream systems below landfills and waste-disposal sites;

- selection and management of waste-disposal sites; and

- effects of acid deposition on stream systems.

To meet the Nation's needs for water-resources information, the program for 1985 has been developed to address the following:

--ground-water contamination,

- -stream quality,

- -water supply and demand, and

- -hydrologic hazards. 
Additional regional needs are addressed by programs for:

--hydrologic effects of fossil fuels and mineral extraction;

--wet 1 ands, lakes, and estuaries; and

--acid rain.

The 1985 program of the North Carol ina District, in cooperation with State and local agencies and with other Federal agencies, addresses most of the issues above and North Carolina needs for waterresources information. A summary of the North Carolina District program for fiscal year 1985 is described in following sections of this report.

\section{SOURCES OF FUNDS}

Funds to support the water-resources activities performed by the Geological Survey in North Carolina are derived from three principal sources.

- Federal Program--Funds for the Federal Program are appropriated by the Congress and are specifically identified in the annual Geological Survey budget. These funds are used to support research, data collection, highpriority topical programs, the coordination of all Federal programs related to collection of water data, and internal support services.

- Federal-State Cooperative Program--Federal funds are appropriated by the Congress and used to match those furnished by State and other tax-supported agencies on a 50-50 basis. These funds are used for a variety of hydrologic data-collection activities and water-resources investigations in which the Geological Survey represents national responsibilities and the cooperating agencies represent State and local interests.

- Other Federal Agencies (OFA) Program--In this program, the funds are transferred to the Geological Survey as reimbursement for work performed at the request of another Federal agency.

Additional sources of funds include unmatched reimbursable funds from State and local government agencies and Federal Energy Regulatory Commission 1 icensees.

The proportion of funding for major programs conducted by the North Carolina District in fiscal year 1985 (October 1, 1984 through September 30,1985 ) is shown in figure 1 . 


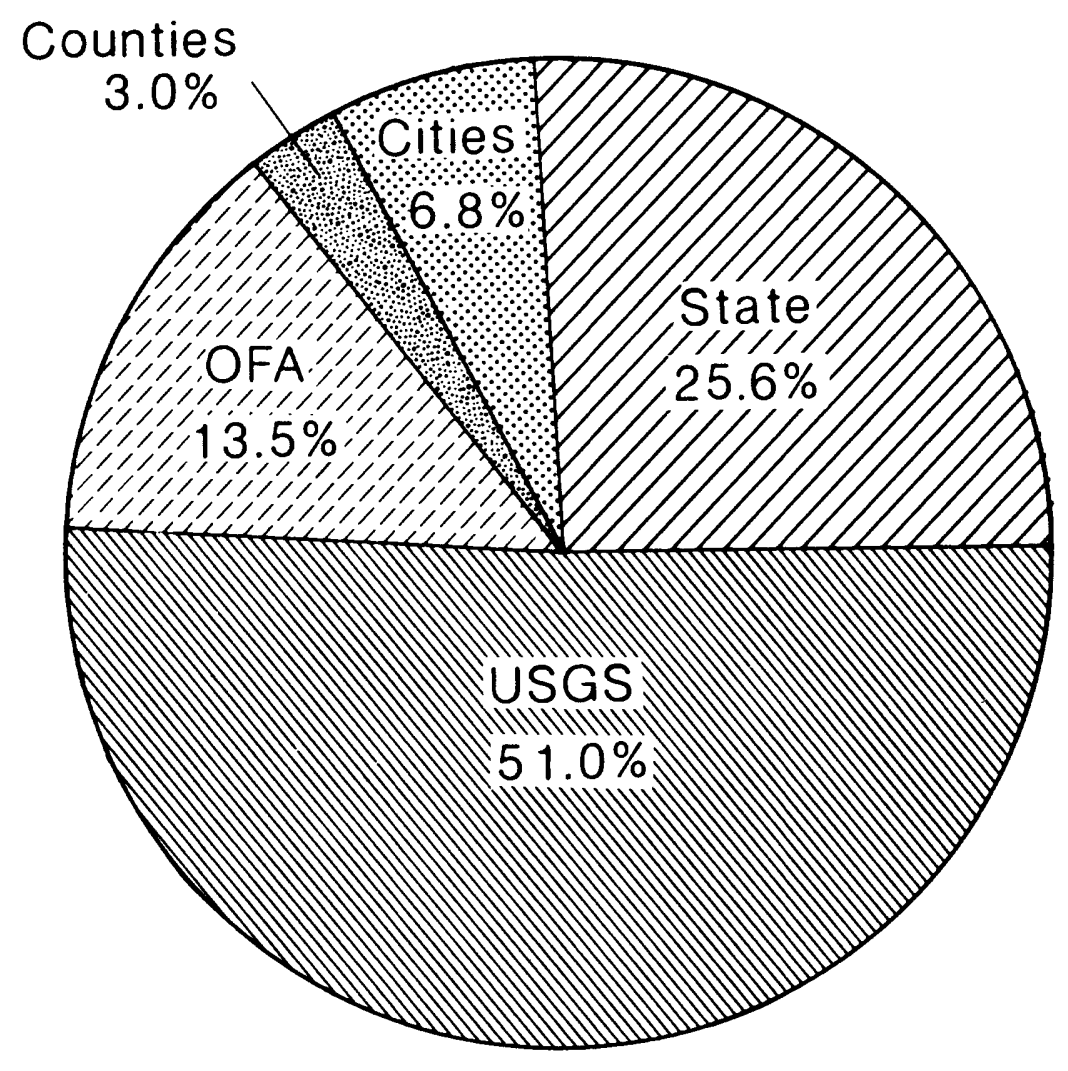

Figure 1.--Proportion of funding for major programs conducted by the North Carolina District in fiscal year 1985. 


\section{COOPERATING AGENCIES}

In 1985, the Geological Survey conducted programs in cooperation with 3 State agencies, 20 local agencies, and 6 Federal agencies. A11 Survey cooperators in North Carolina are listed below.

\section{$\underline{\text { State Agencies }}$}

North Carolina Department of Natural Resources and Community Development

North Carolina Department of Human Resources

North Carolina Department of Transportation

\section{Local Agencies}

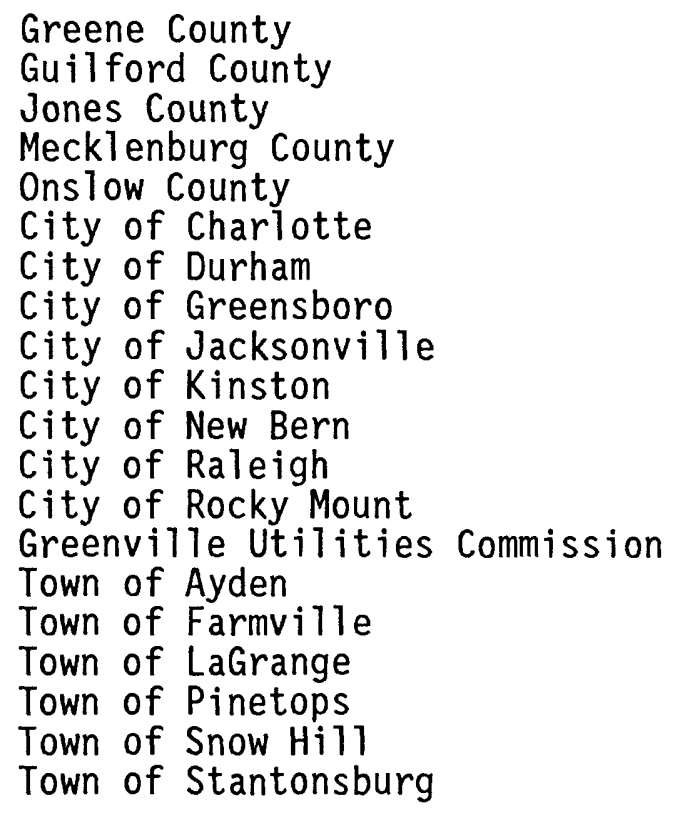

\section{Federal Agencies}

Environmental Protection Agency

Federal Emergency Management Agency

Federal Energy Regulatory Commission

Tennessee Valley Authority

U. S. Army Corps of Engineers

U. S. Soil Conservation Service 


\section{DISTRICT ORGANIZATION}

The North Carolina District consists of two operating sections and three support units (fig. 2). Water-resources projects conducted by the District are assigned to both operating sections with responsibility for a project assigned to a project chief. The North Carolina District Office is in Raleigh; field offices are in Asheville and Statesville, and a project office is in Charlotte (fig. 3). The North Carolina District is assisted and advised by Geological Survey research centers, laboratories, technical consultants, and training centers maintained throughout the United States.

NORTH CAROLINA DISTRICT

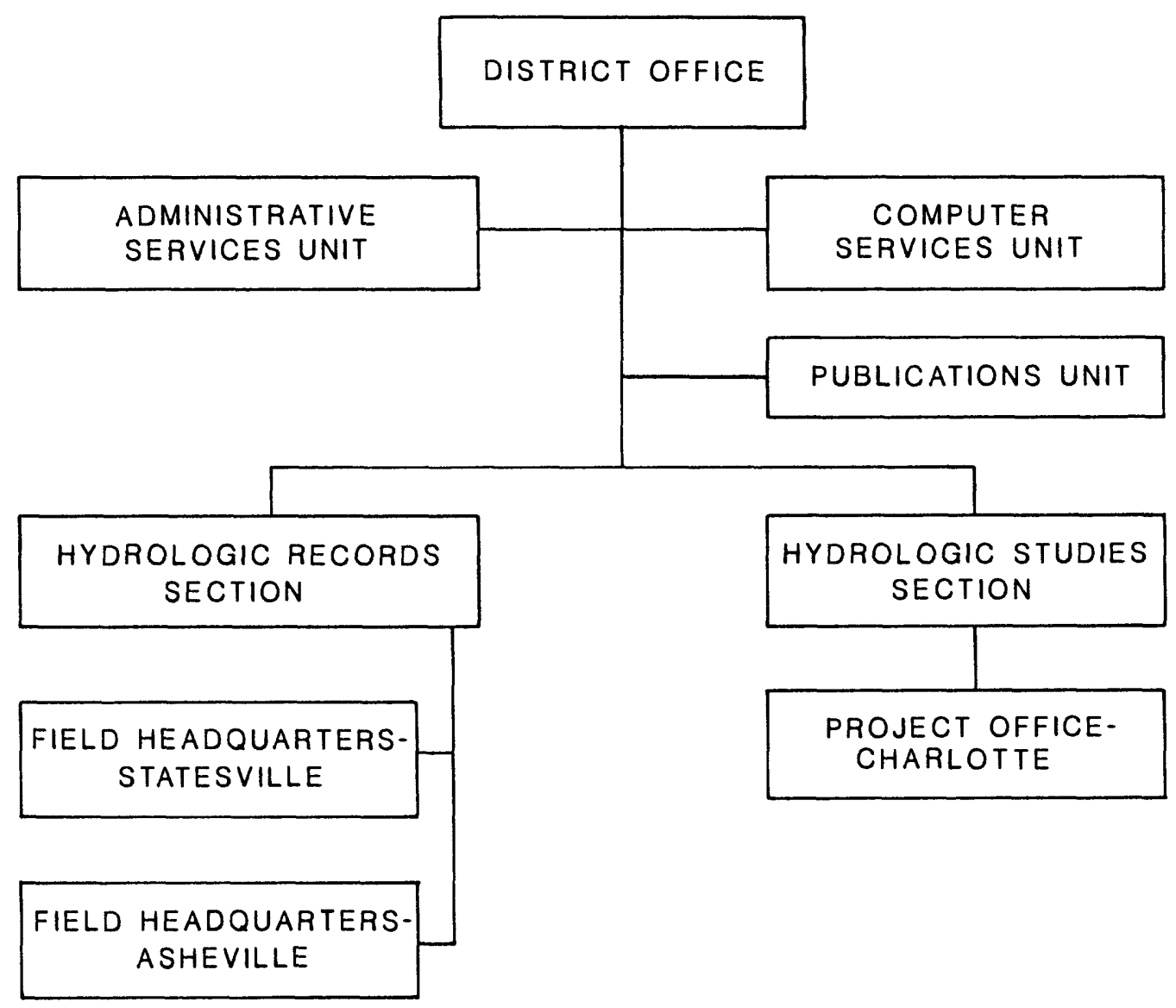

Figure 2.--Organizational chart for the North Carolina District. 


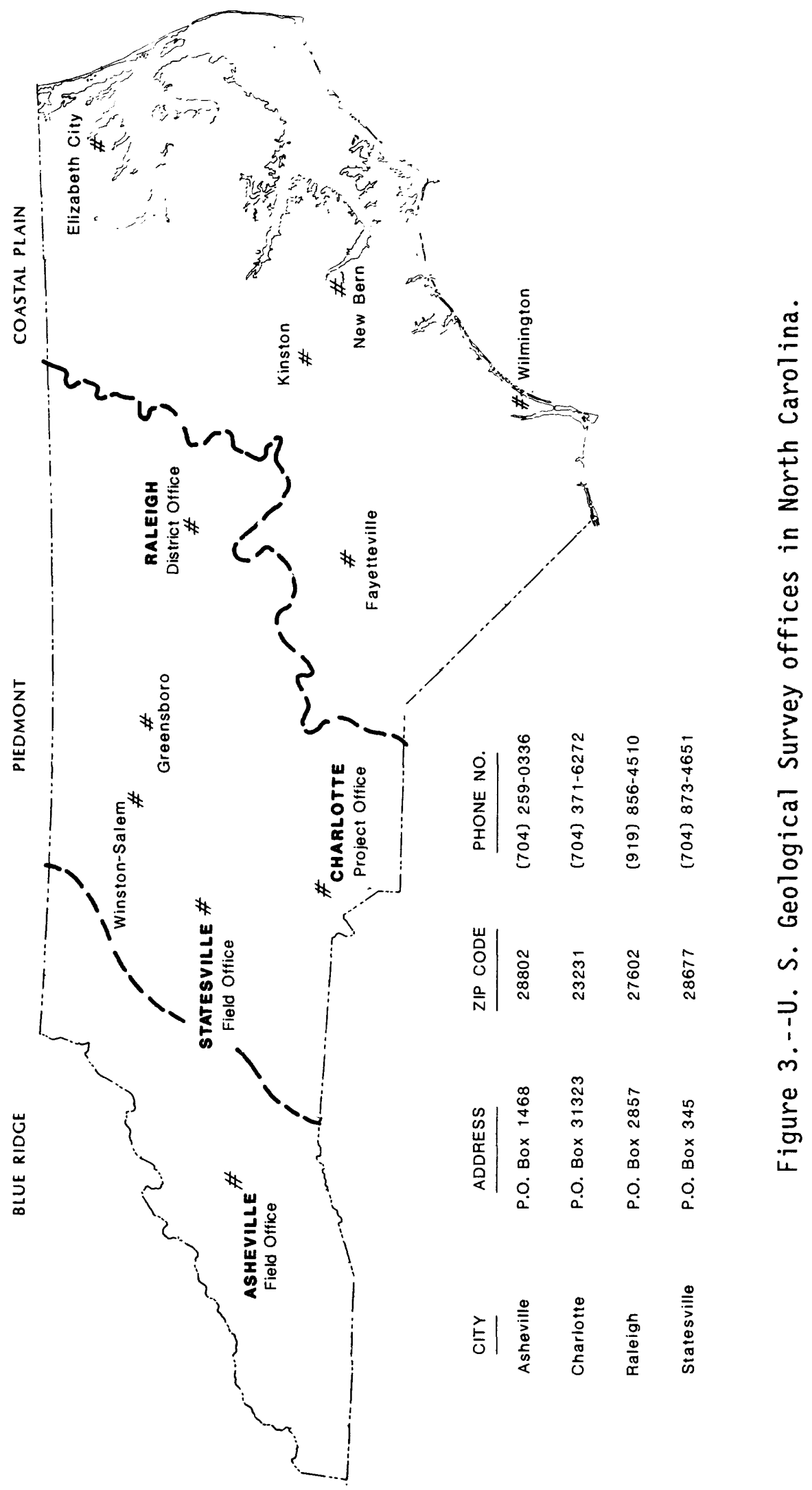


The Hydrologic Records Section proposes, plans, and conducts the hydrologic records program and conducts some interpretive surfacewater investigations. Major activities include collection, processing, and publication of records from statewide surface-water, ground-water, and water-quality monitoring networks as we 11 as publishing interpretive reports on regionalization of streamflow characteristics, sedimentation, stream quality, effects from various land-management practices, channelization impacts, urban hydrology, and flood mapping. The section also handles most requests for information.

Hydrologic Records activities also include training, network design, and programs to maintain technical quality control and assurance of data collected and processed. Section personnel maintain close contact with cooperators, consult with State, local and other Federal agencies and others to develop data-collection programs of local and national priority and provide information on availability of data. The section also provides technical assistance in the planning and design of data-collection activities to support other interpretive investigations conducted in the District.

The Hydrologic Studies Section proposes, plans, and conducts water-resources investigations describing the occurrence, availability, and physical, chemical, and biological characteristics of surface- and ground-water resources in North Carolina. The Section is also responsible for supervision of the Charlotte project office.

Examples of types of investigations conducted by the Section are: effects of ground-water development; saltwater encroachment; effects of waste disposal on the ground-water system; ground-water supply potential; ground-water use; aquifer mapping; effects of hazardouswaste disposal; aquifer characteristics and effects of hydraulic stress upon various aquifer systems; sediment, stream-quality, and biologic conditions; acid deposition; effects of landfills on the ground- and surface-water system; urban hydrology; and, channelization impacts. Many of these studies involve the development, calibration, and use of digital simulation models as a means of evaluation. Digital models are also used for hydrologic mapping and design of monitoring networks.

Results of investigations are disseminated through published scientific reports, correspondence, personnel contacts, and formal presentations at various conferences and meetings, locally, nationally, and internationally. Studies Section personnel are responsible for maintaining contact with cooperators and other parts of the scientific community on water problems, identifying needed investigations, and informing cooperators of the status and progress of current investigations. The Section also provides coordination and technical assistance to the District staff on computer modeling of ground-water systems and aquifer testing and drilling. 
The Publications Unit provides overall support in the planning, management, and production of interpretive reports in the District. Unit personnel provide assistance to project and section chiefs in the planning, design, and preparation of reports and manuscripts, insuring full compliance with current District, Region, and Division policy and technical and editorial quality. The unit provides support services such as typing, aiding project chiefs in obtaining base maps, drafting, editing, coordinating the review process, and maintaining support files and a tracking system. Unit personnel offer or arrange for the training of authors, answer requests for publications, and maintain the District library.

The Computer Services Unit provides complete data processing and related support services, such as data transcription, programming support, and systems analysis to the operating Sections and the Administrative Services Unit. The Unit staff operates and maintains the computer facilities for the District, including project and field offices. The Unit provides technical assistance to the project staff on the implementation and execution of various digital models, data base programs, and software required for hydrologic analysis. The Unit periodically reviews and recommends improved data processing procedures and upgrading of hardware and software systems to assure that the most economical and practical means are used in providing data processing services to the District.

The Administrative Services Unit provides budget formulation and execution, financial management, procurement activities, management analysis and improvement, and general services and office support.

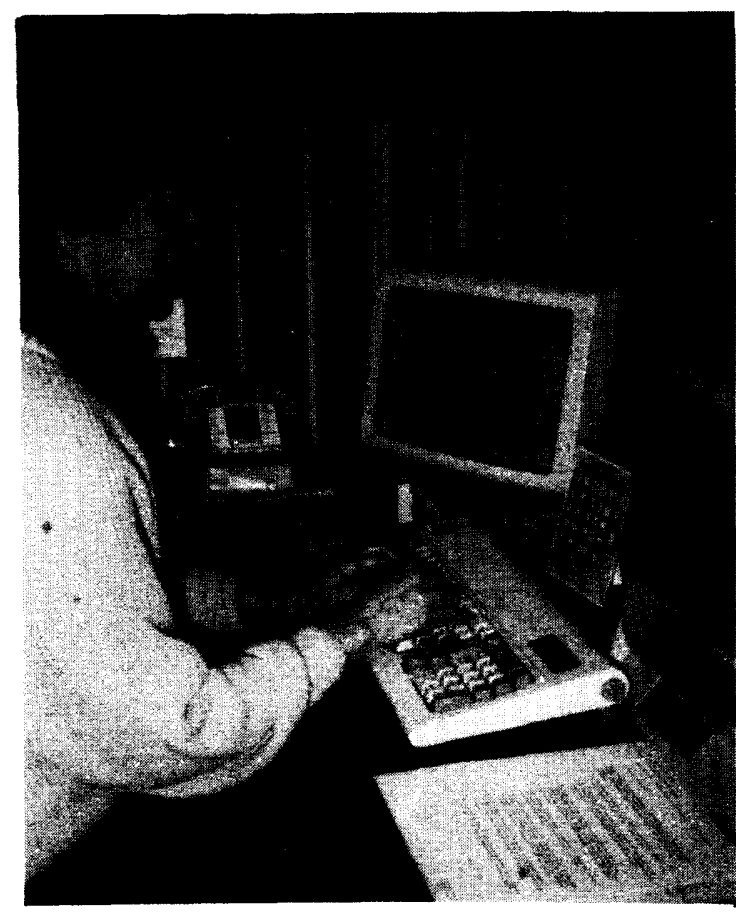

Lending administrative support through word processing.

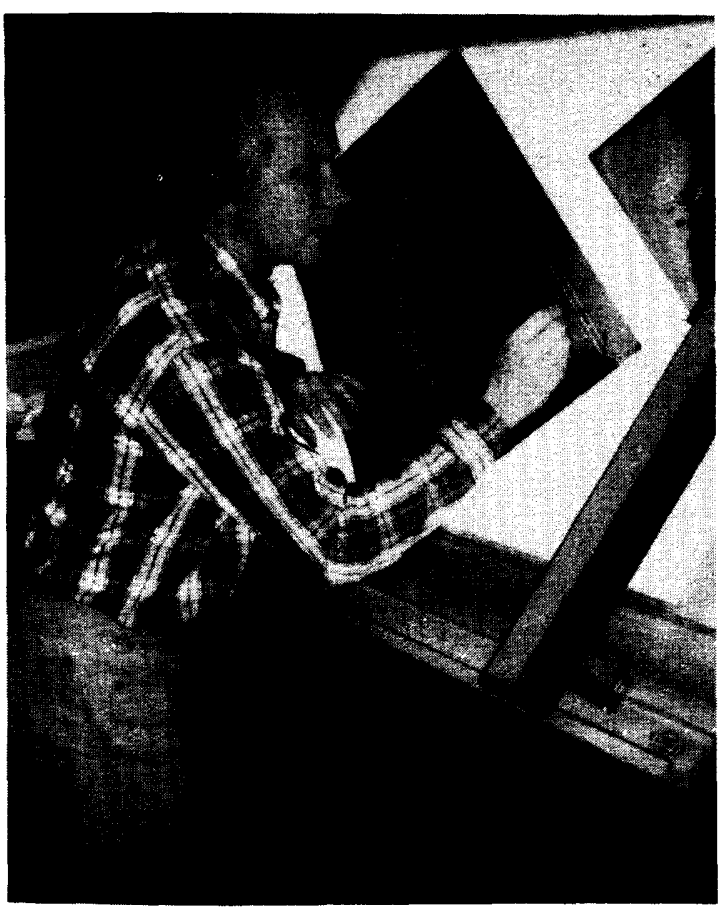

Preparation of illustrations for technical reports. 


\section{WATER-RESOURCES CONDITIONS}

Precipitation during the 1985 water year (October 1, 1984 through September 30, 1985) was below normal throughout most of the State with a large part of the deficit occurring during the months of March and. April. The deficit for the water year as reported by the National Oceanic and Atmospheric Administration for Asheville, Charlotte, and Raleigh was 18.06 inches, 3.37 inches, and 9.07 inches, respectively (fig. 6). Rainfall for March was the minimum of record at Charlotte, Greensboro, and Asheville (downtown). Rainfall for April and May was also minimal; the spring of 1985 (March, Apri1, and May) was the driest of record. Spring rainfall at Asheville was 8.06 inches below normal. Rainfall reported for many areas of the Coastal Plain was less than 4 inches during the spring months which delayed planting of crops and caused general concern for possible water shortages. Rainfall amounts for the months of May and June were al so minimal. Temperature was above normal during the spring, and numerous forest fires occurred in the western Piedmont and eastern Coastal Plain.

Below average streamflow generally prevailed across North Carolina during the 1985 water year. Annual flows were in the lowest 25 percent of record statewide. Comparison of annual discharge for the 1985 water year to median discharge, 1951-80 water years, for selected representative stations is as follows: French Broad River at Asheville, 63 percent; South Yadkin River near Mocksville, 70 percent; Deep River near Moncure, 73 percent; and Contentnea Creek at Hookerton, 65 percent (sites 1, 3, 5, and 7, fig. 4). Comparisons of monthly and annual mean discharges for the 1985 water year to the median of the monthly and annual mean discharges for the period 195180 are shown in figure 5 .

Streamflow was near average in the Coastal Plain and Piedmont provinces and below average in the Blue Ridge province at the beginning of the water year. Monthly mean flow ranged from approximately 60 to 85 percent of median monthly flow from November through January. In February, streamflow was near or slightly above average statewide for the first time in four months. Record low rainfall for March, combined with above normal temperatures, caused streamflow to fall significantly below average. Near record low flows occurred on the French Broad River at Asheville and South Yadkin River near Mocksville (sites 1 and 3, fig. 4). April mean flow ranged from 35 to 55 percent of median monthly flow (fig 5). 


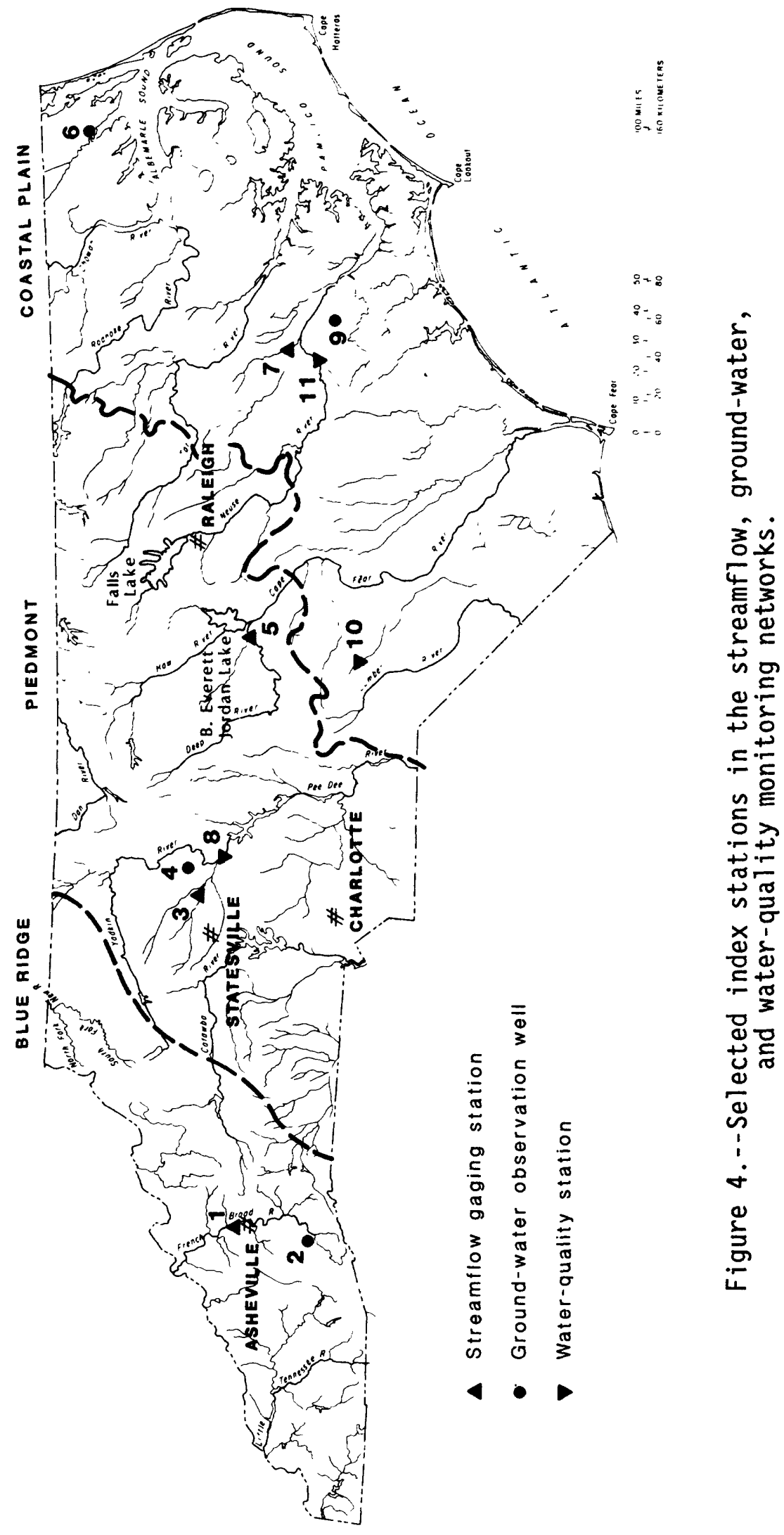



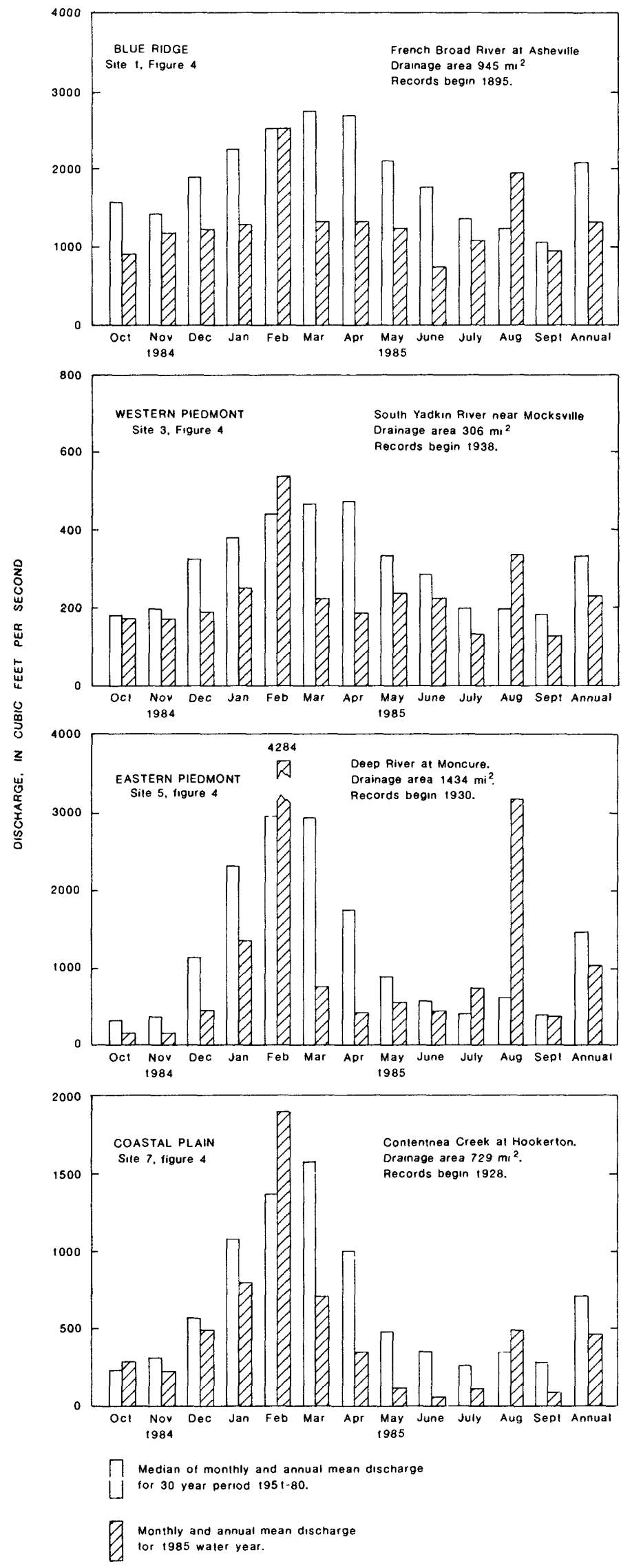

Figure 5.--Variation of discharge at selected long-term index stations for the 1985 water year with median discharge for the period 1951-80. 


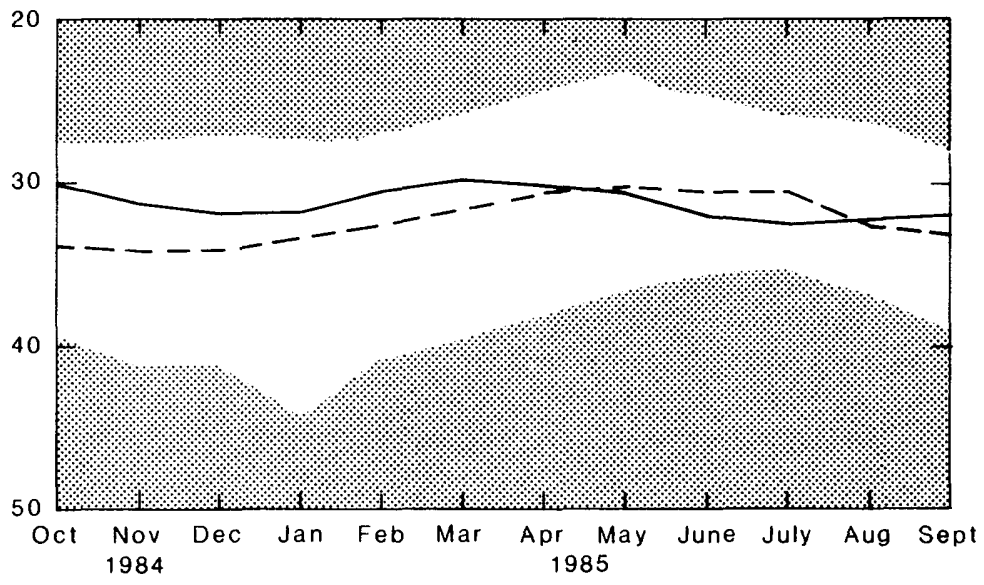

NC-144 Transylvania County, in granite, 58 feet deep. Records begin 1932.

PIEDMONT

Site 4 , figure 4

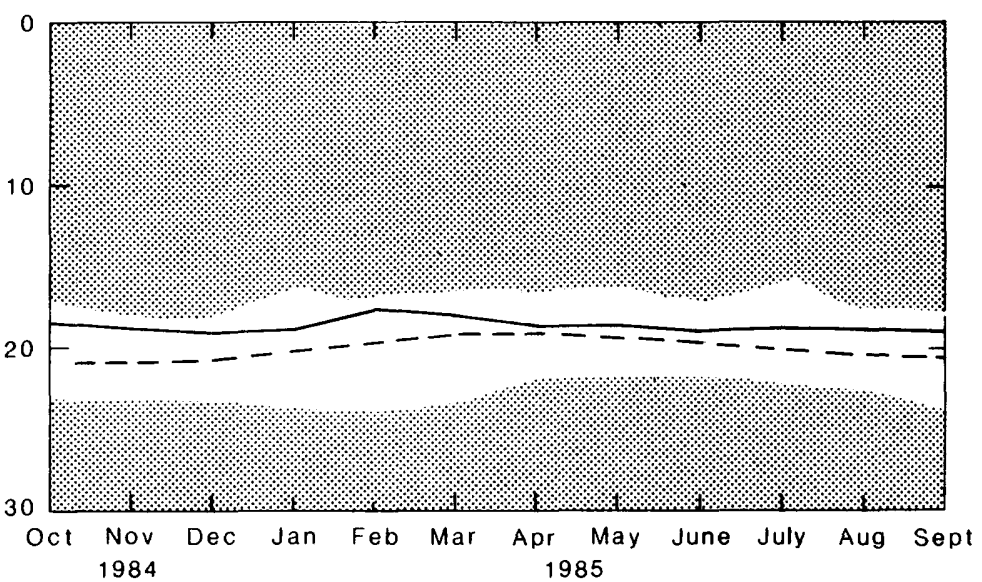

NC-142 Davie County, in granite, 31 teet deep Records begin 1931.

COASTAL PLAIN

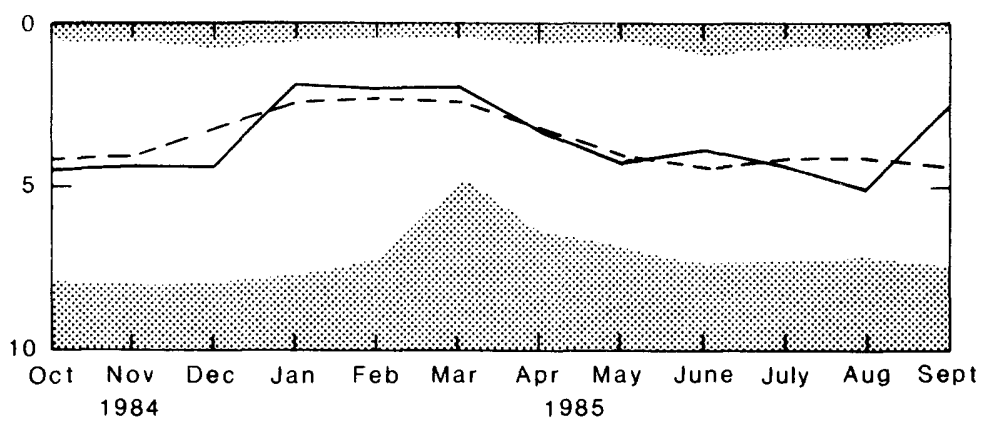

NC-143 Pasquotank County, in sand, 10 feet deep. Records begin 1936.

$$
\text { EXPLANATION }
$$

Unshaded area indicates range between highest and lowest record for the month.

Dashed line indicates average of monthly levels, in previous years.

Solrd line indicates level for 1985 water year. 
Record minimum daily and monthly mean flows for June occurred at Contentnea Creek at Hookerton (site 7, fig. 4); but above-normal rainfall caused minor flooding in a few areas, including charlotte and Statesville. Streamflow remained significantly below average until July 23, when tropical storm Bob moved into the State; locally heavy thunderstorms produced as much as 6 inches of rainfall in a few areas. On August 17 and 18, rainfall from hurricane Danny caused 5- to 10year floods in some areas of the Piedmont province. Monthly mean flows for August were above average statewide for the first time since February. Hurricane Gloria caused minor localized flooding on September 27 and 28 in the extreme eastern and northeastern counties.

Monthly mean flows for the 1985 water year for selected index stations as compared to long-term median monthly flows are as follows:

\section{Monthly Flow as Percent of Median}

Contentnea Creek South Yadkin River French Broad River at Hookerton near Mocksville at Asheville

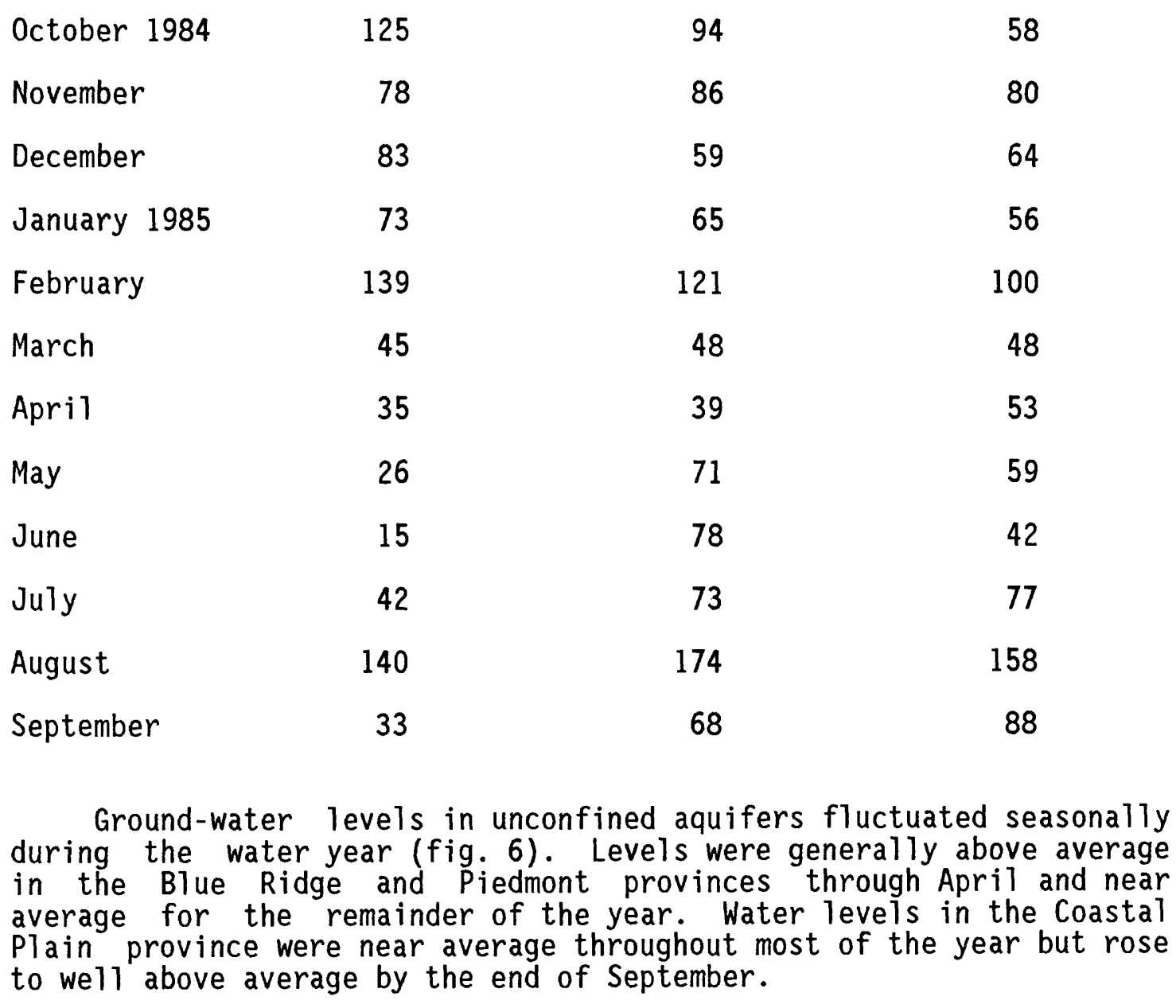


Levels in confined aquifers which are affected by withdrawals for municipal and industrial use in some areas of the central and northern Coastal Plain declined to record lows. Record-low levels occurred in wells in Carteret, Chowan, Craven, Hertford, Lenoir, and Onslow Counties.

Ground-water withdrawals in the Coastal $\mathrm{Plain}$ have resulted in declining water levels for a number of years. An example of this trend is illustrated in figure 7 by the hydrograph of water levels at New Bern's well field located at Cove City for the period 1965-85. Water level declines in the northern and central parts of the Coastal Plain are illustrated on the map (figure 7). Declines of more than 100 feet have been observed. Further declines are expected as withdrawals continue to increase.

The chemical quality of selected streams varied during the water year but was near the long-term seasonal average. Concentrations of major dissolved constituents, such as chloride, sodium, and calcium, were near long-term averages but were slightly greater than concentrations for 1984. Specific conductance, an indicator of the concentration of dissolved constituents, was measured at about 20 sites across the State. Specific conductance was above average in the Piedmont and Coastal Plain provinces during the year, except for october and February when it was slightly below average. The variation of monthly and annual means of specific conductance at selected index sites in the Piedmont and Coastal Plain provinces during the water year, and for the reference period 1975-85, is shown in figure 8 .

As in 1983 and 1984, concentrations of nitrite plus nitrate nitrogen occasionally exceeded $10 \mathrm{mg} / \mathrm{L}$ at sites on several tributary streams to B. Everett Jordan Lake and exceeded $10 \mathrm{mg} / \mathrm{L}$ several times on one tributary to Falls Lake (fig. 4). The high concentrations of manganese, reported in previous reports for tributaries to the Falls and B. Everett Jordan Lakes and for outflow from the lakes, were not observed during 1985.

Beginning in 1ate 1983, an investigation was begun to study the effects of precipitation on stream chemistry in the Sandhills region of the Coastal Plain (site 10, fig. 4). Rainfall during the year continued to be acid, normally having pH values of about 4.5 units, with a minimum value of 3.9 units. $\mathrm{A}$ pH of 3.8 units was measured on July 25 in Jordan Creek near Silver Hill. Typical pH values for streams originating in the Sandhills generally range from about 4 to 5 units. 

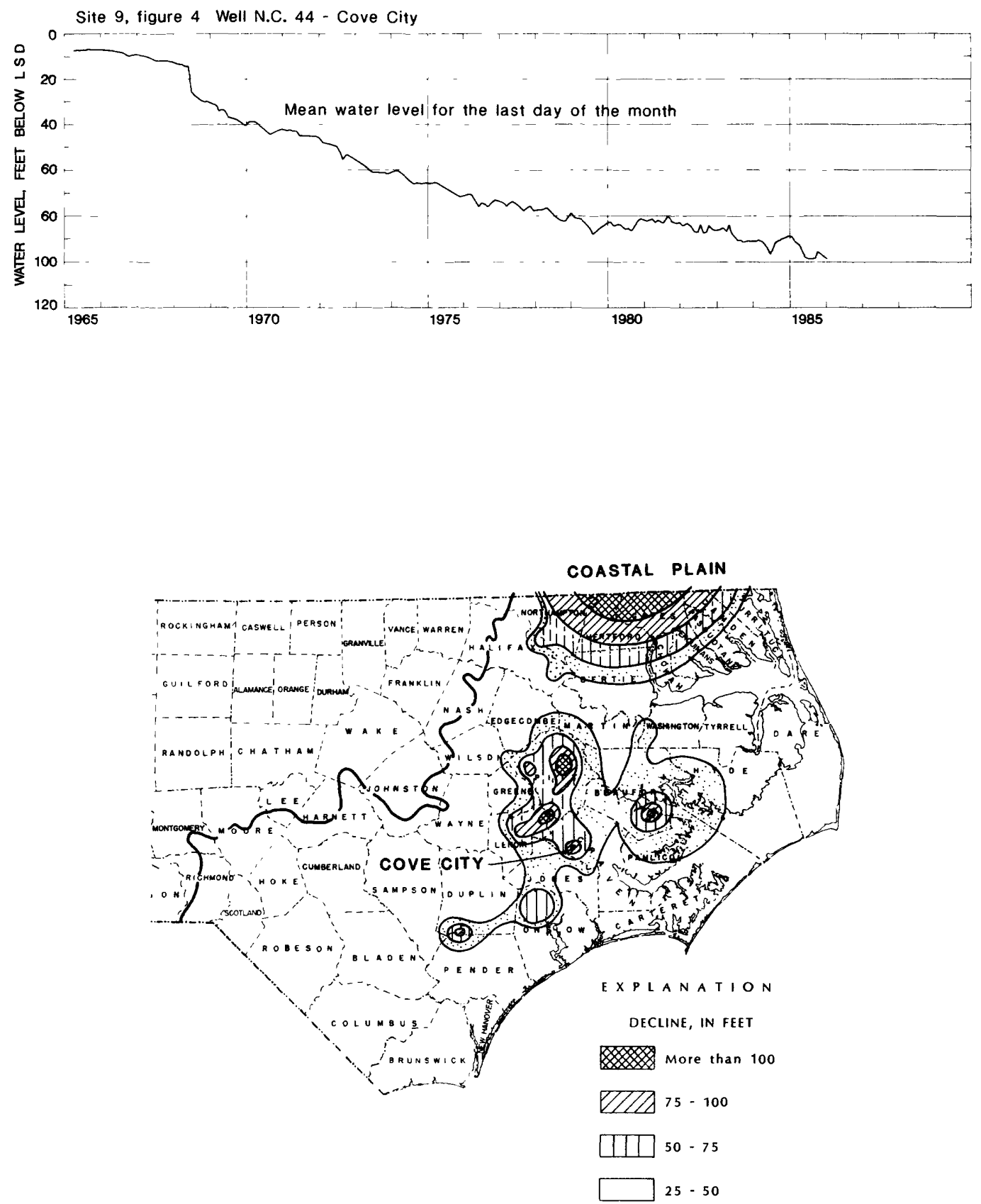

Figure 7.--Declining ground-water levels at Cove City and water-level declines in the Coastal Plain province. 


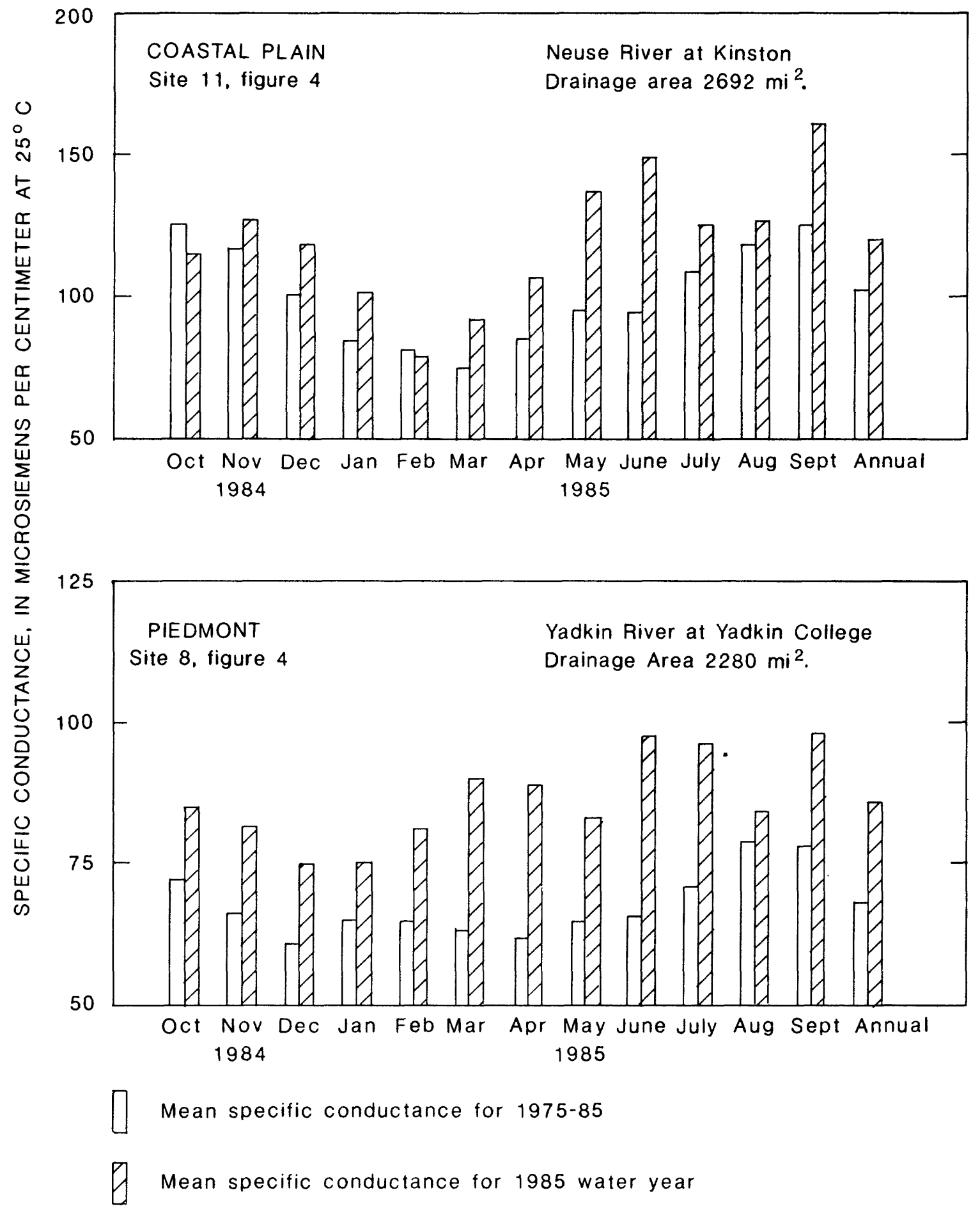

Figure 8.--Variation of specific conductance at selected long-term stations during the 1985 water year with means for the period 1975-85. 


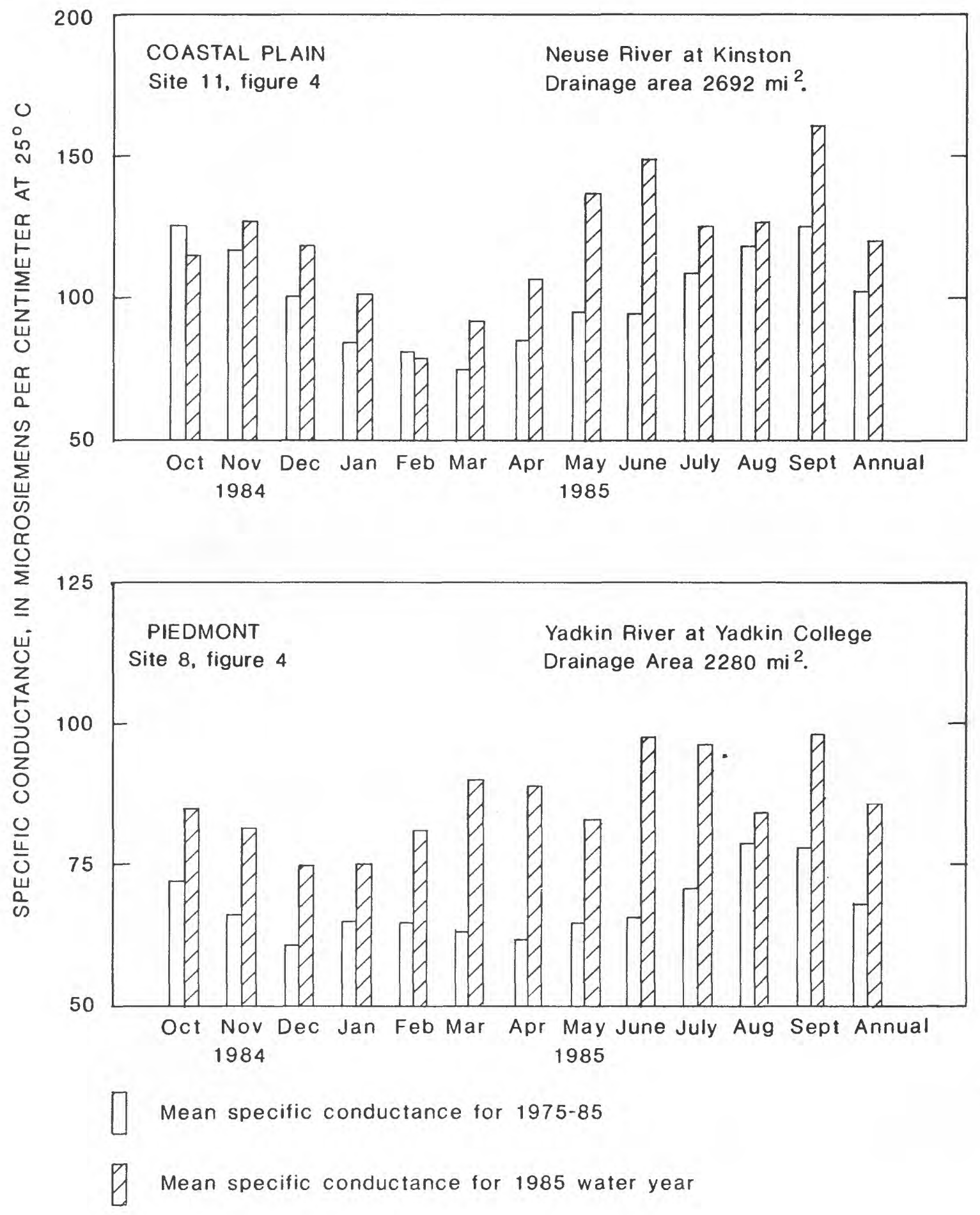

Figure 8.--Variation of specific conductance at selected long-term stations during the 1985 water year with means for the period 1975-85. 
Accelerated erosion of soils from prime farmlands continues to be a problem, especially in the rolling Piedmont and Blue Ridge provinces. An investigation of the effects of 1 and-management practices on soil erosion, begun in 1984 in northern Guilford County, shows that levels of suspended sediment in runoff from land having poor management practices can be 4 to 5 times greater than those from we11-managed 1ands. Concentrations of suspended sediment exceeded $57,000 \mathrm{mg} / \mathrm{L}$ in storm runoff from one 6 -acre tract, which was not contoured and did not have grassed waterways. This concentration was more than 100 times greater than concentrations normally expected in rural Piedmont streams (during moderate storm runoff) and almost 1000 times greater than concentrations occurring in totally forested basins in the Piedmont.

Daily concentrations of suspended sediment for Yadkin River at Yadkin College (site 8, fig 4), a long-term sediment station, are used to define trends (fig. 9). The sediment-transport load for the water year was less than the average annual load for the period 1951-85.

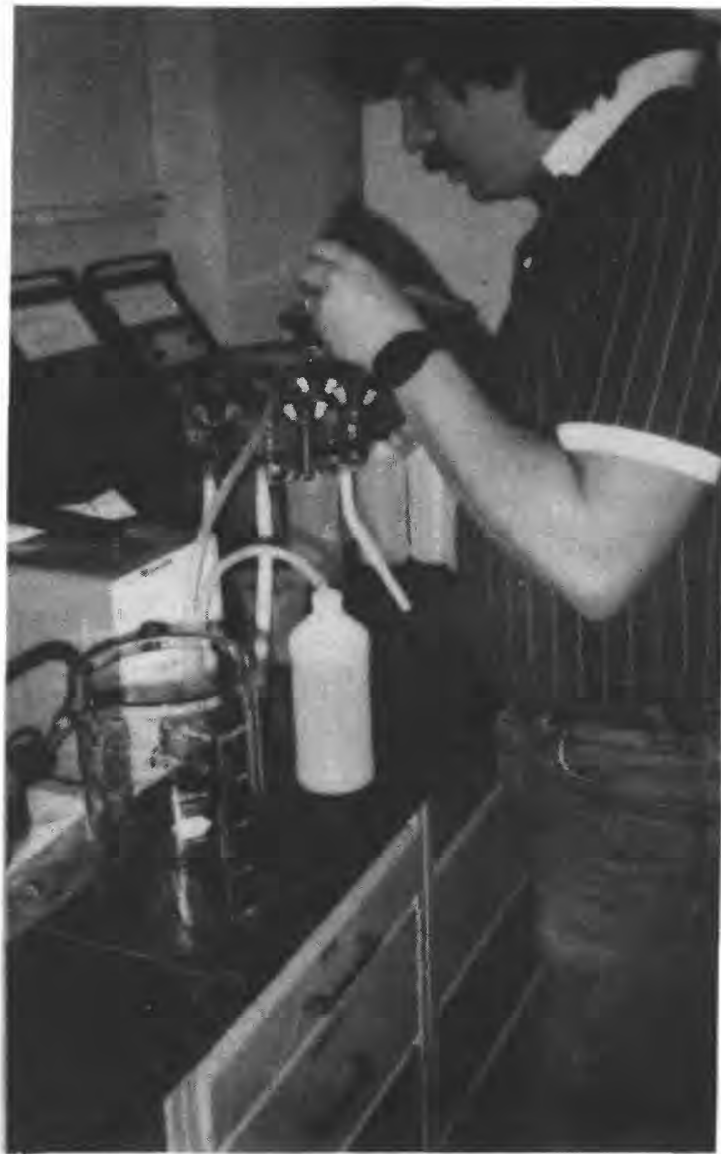

Filtering water samples to determine dissolved constituents.

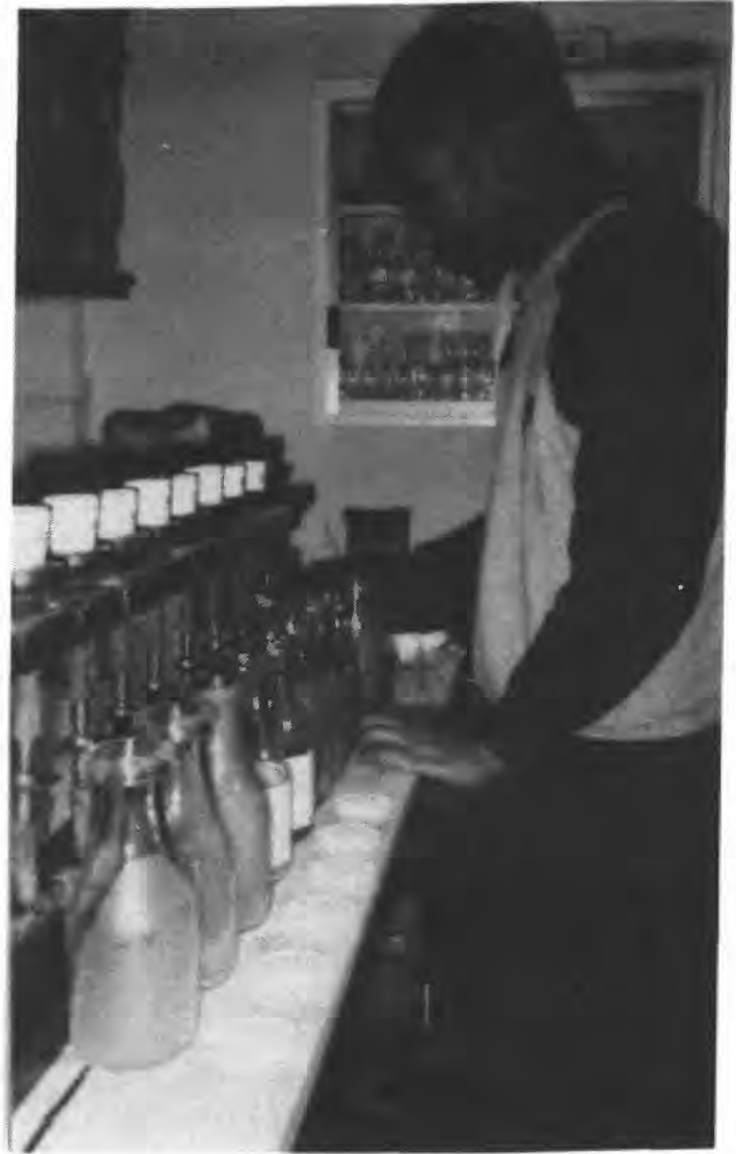

Determining sediment concentration in stream water. 


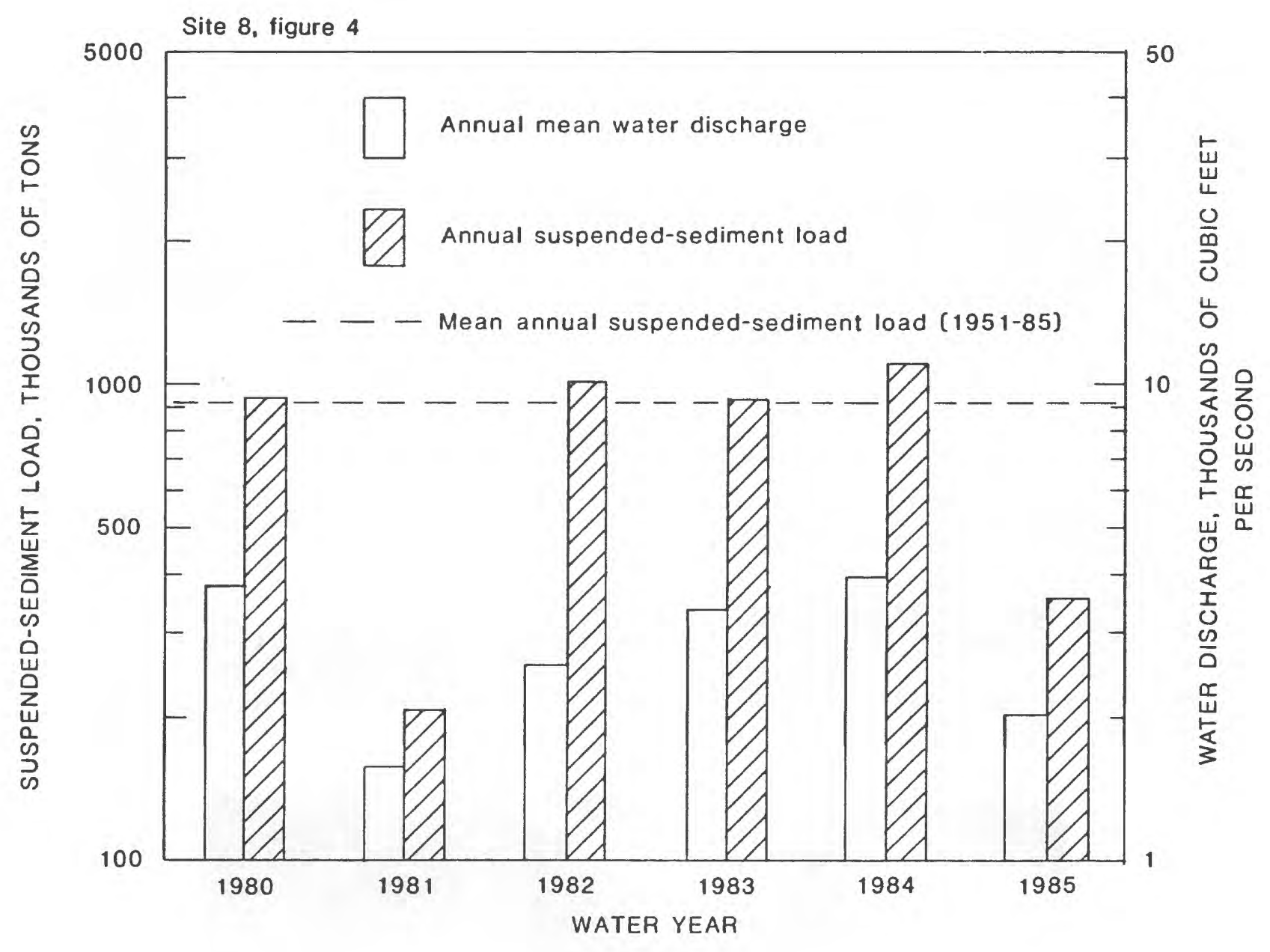

Figure 9.--Variation of total annual suspended-sediment loads and mean water discharges at Yadkin River at Yadkin College, 1980-85. 


\section{WATER-RESOURCES ACTIVITIES}

This section describes the water-resources programs and activities conducted by the Survey in North Carolina in cooperation with State, local, and other Federal agencies. These programs and activities are conducted by both the Hydrologic Records and Hydrologic Studies Sections. The description of significant activities includes a statement of the problem, objective, approach, progress during the year, and plans for next year.

\section{Hydrologic Records}

Hydrologic records activities include the routine collection and processing of data from streamflow, ground-water, water-quality, and sediment stations located across the State. Data for these stations are processed, analyzed, and stored in the National WATSTORE data base of the Survey located in Reston, Virginia, and are available upon request. Data for selected stations are published as part of an annual report entitled, "Water-Resources Data for North Carolina," and other formal publications of the Survey.

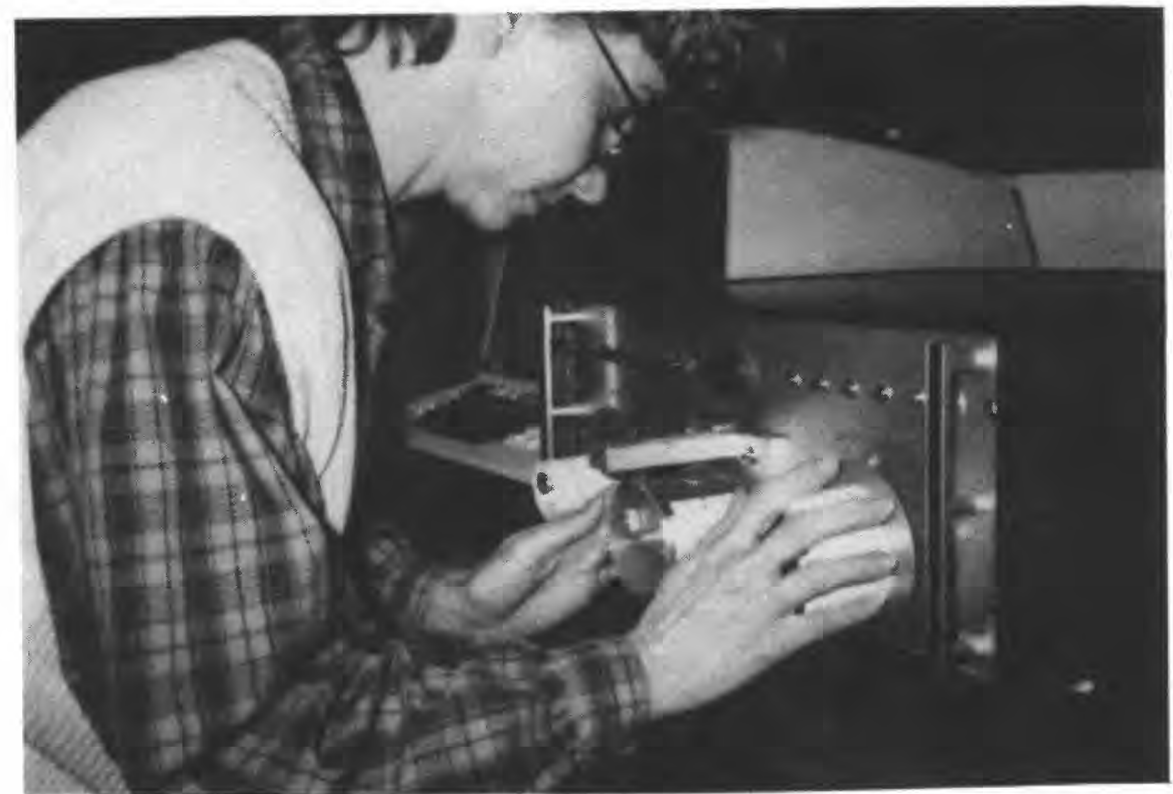

Processing punch tapes from analog digital recorders. 


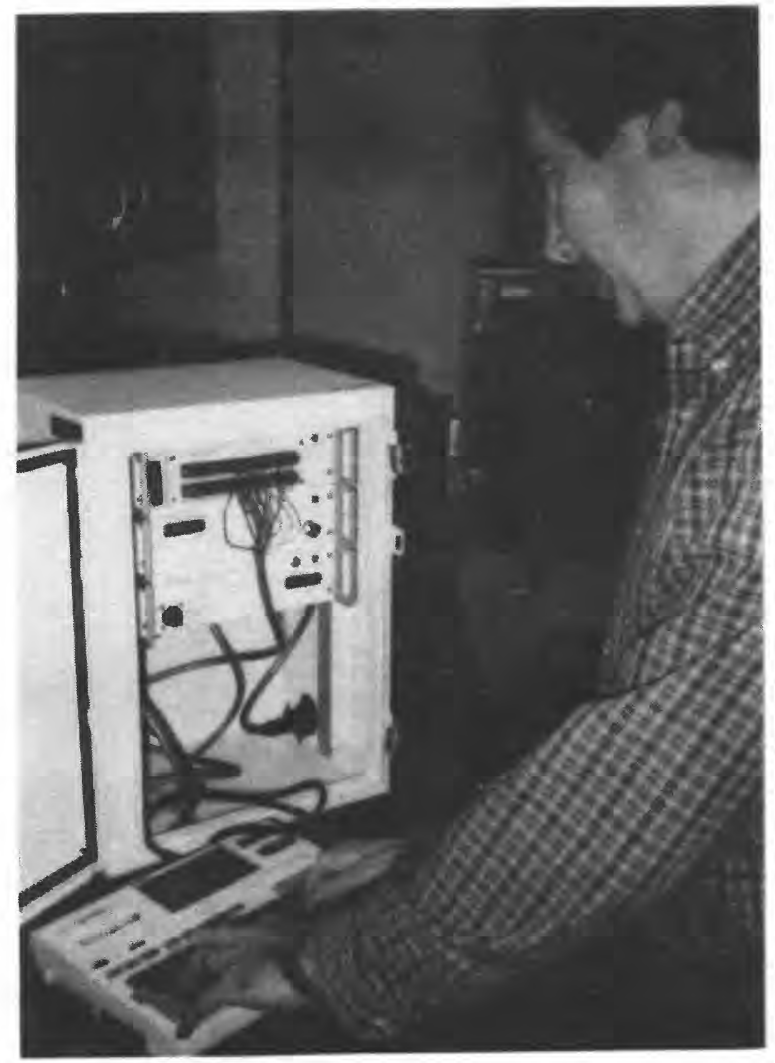

Preparing to transmit stream-stage data to the GOES satellite for relay to ground-receiver stations.
Project: (NC 00-001) Streamflow Network in North Carolina

\section{Location: Statewide}

Project Chief: N. Macon Jackson, Jr. Period of Project: Continuous since 1927

Cooperation: Federal, State, Municipal, and others

Problem: Surface-water information is needed for purposes of surveillance, planning, design, hazard warning, and operation and management in water-related fields, such as: water supply, hydroelectric power, flood control, irrigation, bridge and culvert design, wildlife management, pollution abatement, flood-plain management, and water-resources development. To provide this information an appropriate data base is necessary.

Objectives: (1) To collect surface-water data sufficient to satisfy needs for current-purpose uses, such as: assessment of water resources, operation of reservoirs or industries, forecasting, disposal of wastes and pollution controls, discharge data to accompany water-quality measurements, compact and legal requirements, and research or special studies. (2) To collect data necessary for analytical studies to define for any location the statistical properties of, and trends in, the occurrence of water in streams, lakes, and estuaries for use in planning and design.

Approach: Standard methods of data collection are used as described in the series, "Techniques of Water-Resources Investigations of the United States Geological Survey." Partial-record gaging will be used instead of complete-record gaging where it serves the required purpose. Locations of the 1986 network stations are shown in figure 10.

Progress: Processing of 1985 water-year's records was completed and the report, "Water-Resources Data for North Carolina, Water Year 1985," was printed and distributed. Processing of 1986 records is current. The report presenting the results of a study of the cost effectiveness of the stream-gaging program was approved and published. Work to develop regional relations for estimating low-flow characteristics of ungaged streams continues. 


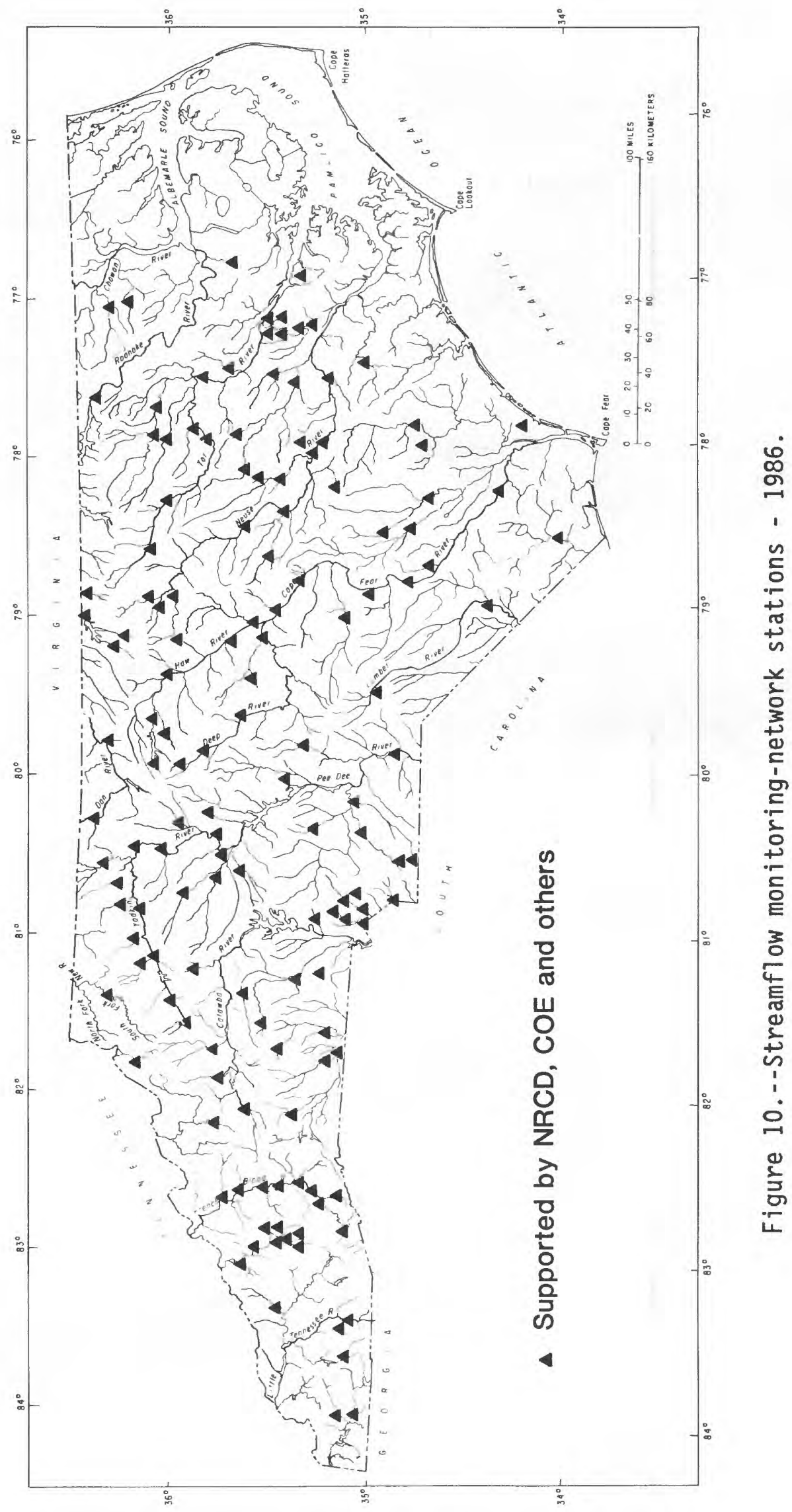




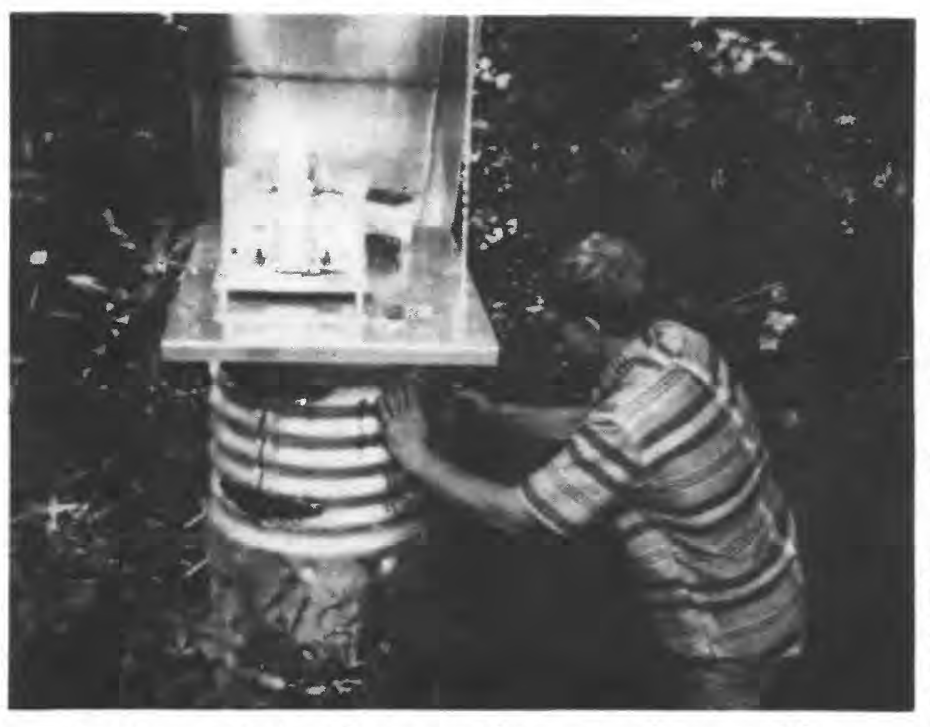

Project: (NC 00-002) Ground-Water Network in North Carolina

Location: Statewide

Project Chief: Ronald W. Coble

Period of Project: Continuous since 1943

Cooperation: North Carolina Department of Natural Resources and Community Development and

Analog digital recorder on observation U. S. Geological Survey well used to detect natural climatic

fluctuations in water table depth.

Problem: Long-term water-level records are needed to evaluate the effects of climatic variations on the recharge to and discharge from the ground-water systems to provide a data base from which to measure the effects of development, to assist in the prediction of future supplies, and to provide data for management of the resource.

Objectives: To collect, analyze, and publish water-level records for North Carolina. These data are needed in the evaluation, planning, development, and management of ground-water resources in North Carolina. These records provide a long-term data base for evaluating general response of the hydrologic system to natural climatic variations and induced stresses; known and potential problems can be defined early enough to allow proper planning and management.

Approach: Evaluation of regional hydrogeology allows broad, general definition of aquifer systems and their boundary conditions. Within this framework and with knowledge of the stresses on the systems, decisions can be made on the best locations for observation wells needed to detect long-term system behavior. This network of wells can be improved as records become available and detailed areal studies of the ground-water system more closely define the aquifers, their properties, and the stresses to which they are subjected. Locations of 1986 network stations are shown in figure 11 .

Progress: Water-level records from the existing USGS network of 45 wells were prepared for publication in the annual data report. The processing of these records has remained current. Three new well sites were chosen and wells were constructed where ground-water and records could be compared to rainfall and streamflow data. 


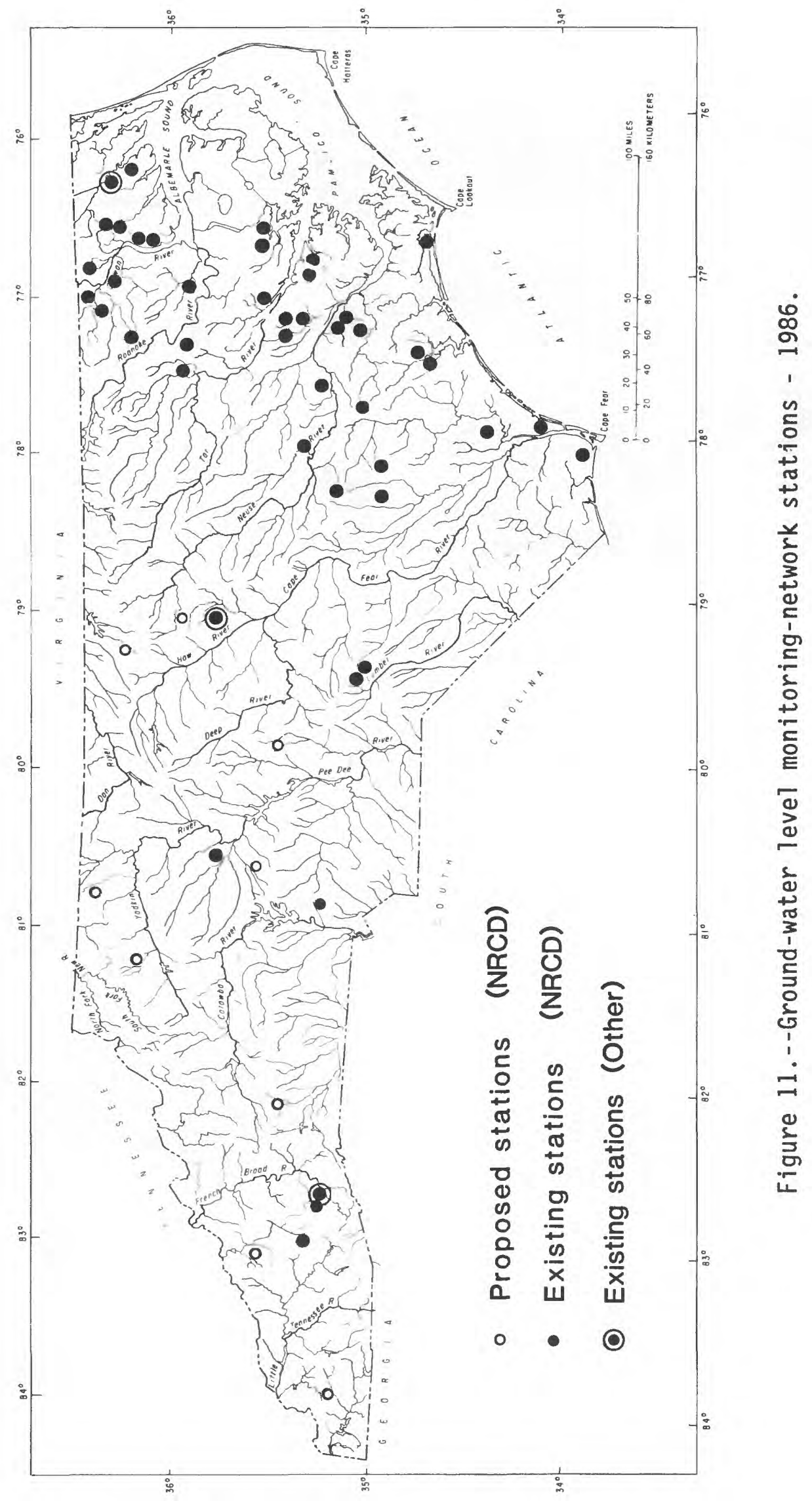




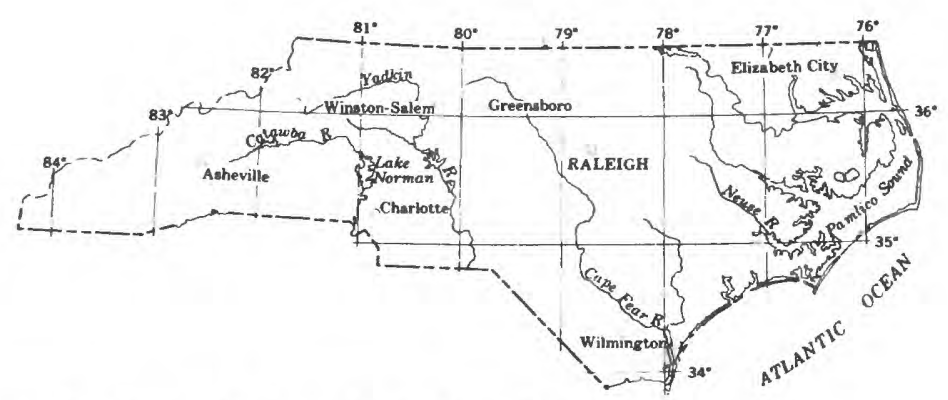

Project: (NC-00-003) Water-Quality Network in North Carol ina

Location: Statewide

Project Chief: Clyde E. Simmons

Period of Project: Continuous since 1943

Cooperation: North Carolina Department of Natural Resources and Community Development and others

Problem: Water-resource planning and water-quality assessment require a nationwide base of standardized information. For intelligent planning and realistic assessment of the water resource, the chemical and physical quality of the rivers and streams must be defined and monitored.

Objectives: To provide a national bank of water-quality data for broad State and Federal planning and action programs and to provide data for Federal management of interstate and international waters.

Approach: Operation of a network of water-quality stations to provide average chemical concentrations, loads, and time trends as required by planning and management agencies. Locations of 1986 network stations are shown in figure 12 .

Progress: During November 1984 to March 1985, the water-quality staff of NRCD and USGS designed a new sampling network, composed of 10 forested (baseline) sites to monitor streams unaffected by man's activities to characterize biology, sediment, trace metals, and various organics and other toxics at background levels. Due to the State's rapid growth and the subsequent loss of acceptable pristine sites, the need for this program is of utmost priority. Although 9 monitoring sites were selected and field equipment purchased to initiate the program, field work was suspended in March 1985 pending resolution of 85 FY funding constraints. Funding was approved for this project by NRCD in August 1985, and efforts have begun to have the baseline monitoring network operational by early 1986 . 


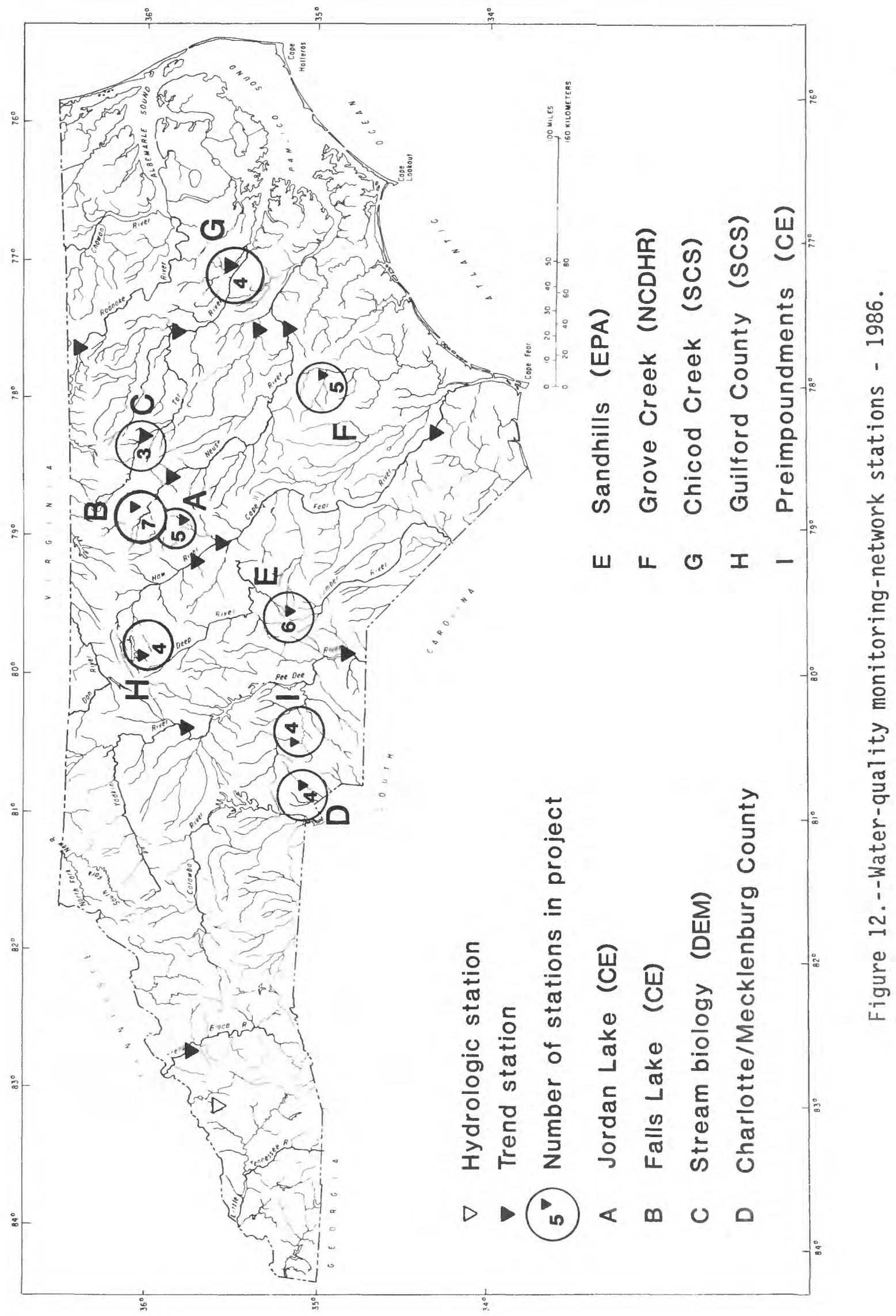




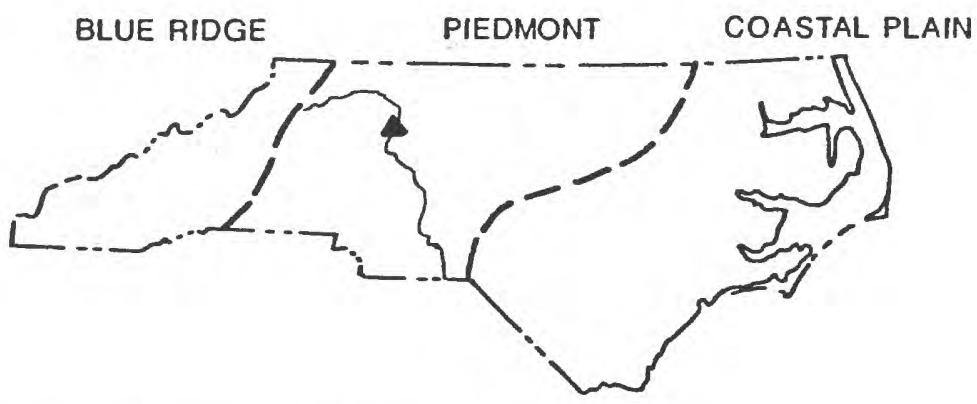

Project: (NC-00-004) Index Sediment Station - Yadkin River

Location: Piedmont Region of North Carolina

Project Cinief: Clyde E. Simmons

Period of Project: Continuous since 1951

\section{Cooperation: Federal}

Problem: Water-resource $p l a n n i n g$ and water-quality assessment require a nationwide base of standardized information. Sediment concentrations and discharges in rivers and streams must be defined and monitored.

Objectives: To provide a national bank of sediment data for use in broad Federal and State planning and action programs and to provide data for Federal management of interstate and waters.

Approach: Establish and operate a nationwide network of sediment stations to provide spatial and temporal averages and trends of sediment concentration, sediment discharge, and particle size of sediment being transported by rivers and streams. The Index Sediment Station for this State is the Yadkin River at Yadkin College.

Progress: The collection of daily sediment samples was continued through the year and additional samples were obtained during high flows. Concentrations of suspended sediment were determined on approximately 400 samples. Construction of a new sediment-sampling shelter and platform was completed and the collection of multivertical samples was begun for verification of cross-section coefficients. Based on results of verification samples collected during low to medium flow, no corrections are required for samples collected at the fixed sampling station during these flow conditions. 


\section{Hydrologic Studies}

Twenty hydrologic investigations are being conducted by the Geological Survey in North Carolina. Included among these are: water use, impacts of channelization, non-point source pollution, sediment characteristics, water-quality characteristics of streams, land-use effects on stream biology, effects of land use on ground-water quality, urban hydrology, and ground water in the Coastal Plain aquifer system. Results of these studies are published in a variety of scientific and technical reports, abstracts, and papers. Reports are provided to local cooperating agencies, and various libraries and repositories.

Collecting soil samples from a hollow-stem auger.
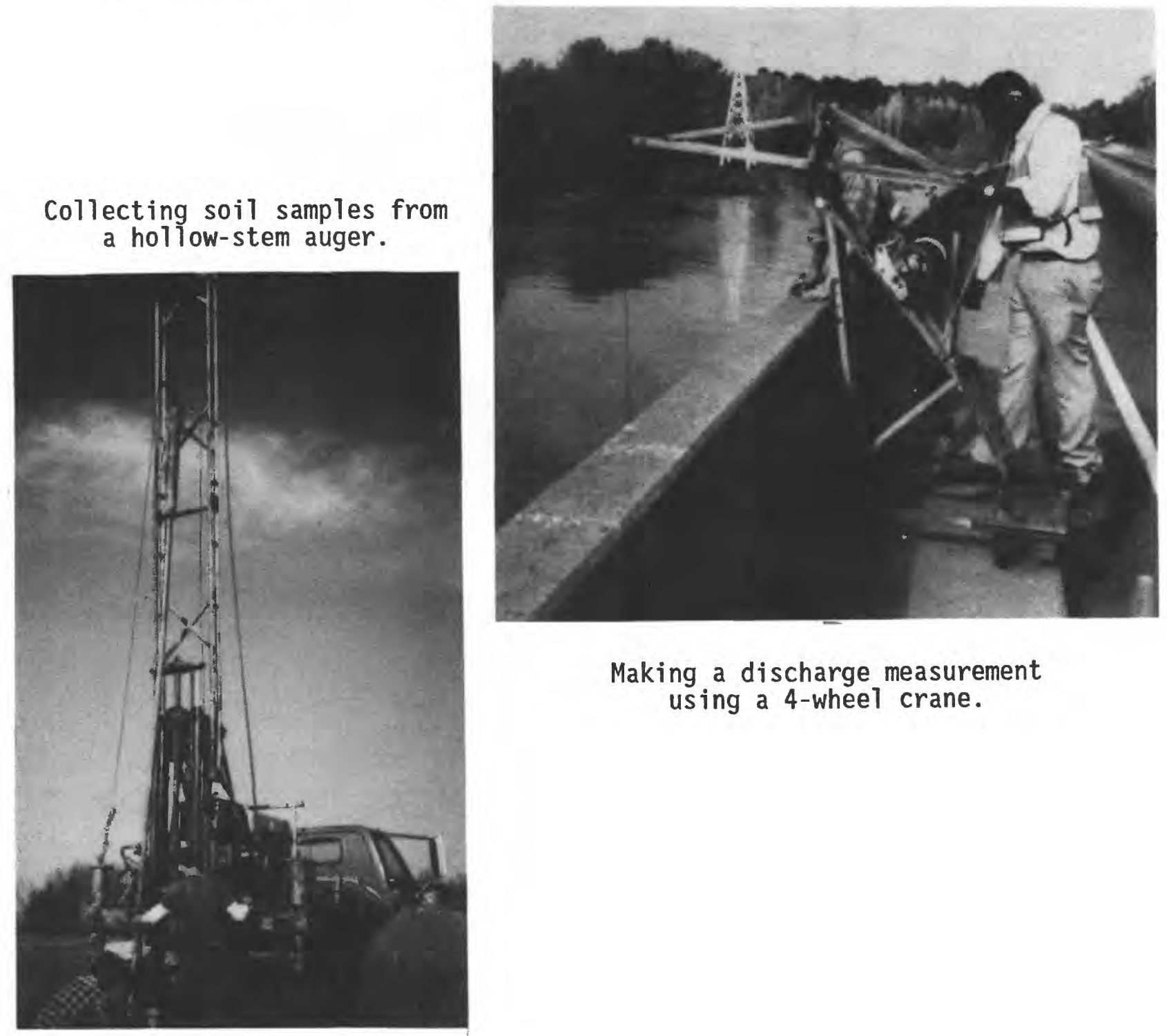

Making a discharge measurement using a 4-wheel crane. 


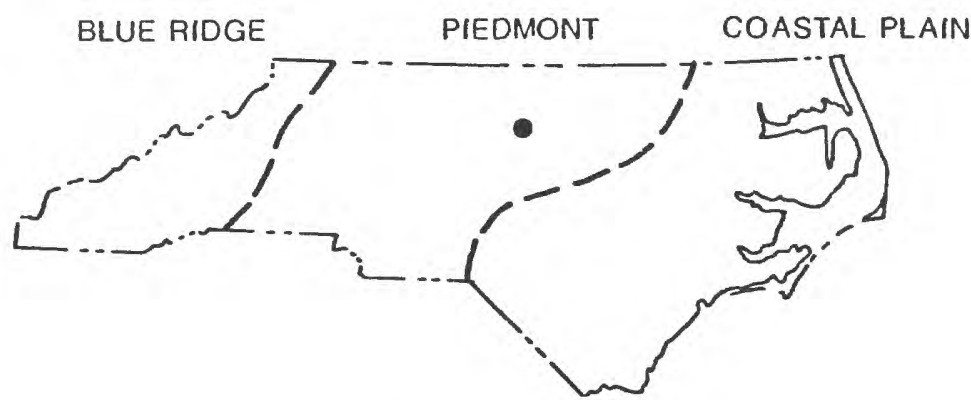

Project: (NC-00-003) Effects of Highway Runoff on Receiving Waters (formerly NC-81-072)

Location: Piedmont province of North Carolina

Project Chief: Douglas A. Harned

Period of Project: $1983-84$

\section{Cooperation: Federal}

Problem: The impact of highway runoff on receiving waters in rural areas is unknown.

Objectives: To evaluate the effects of runoff from a major highway on stream quality of a small rural basin in the Piedmont Province of North Carolina.

Approach: Streamflow, water quality, and meterological data were collected at 5 monitoring sites within the basin of Sevenmile Creek, Orange County, North Carolina. Three sites were stream monitoring sites and two were highway monitoring sites. One stream monitoring site served as the control station for evaluating the impact of highway runoff. Data was collected over a full range of flow conditions for a 12-month period. Laboratory analyses of major constituents, nutrients, metals, and biological parameters were made.

Progress: The hydrologic data were collected under project NC 81-072. The report, "Impact of Highway Runoff on Stream Quality in the Sevenmile Creek Basin near Efland, North Carolina," has been completed. Colleague review of the report has been completed, and a revised version of the report is being prepared. 


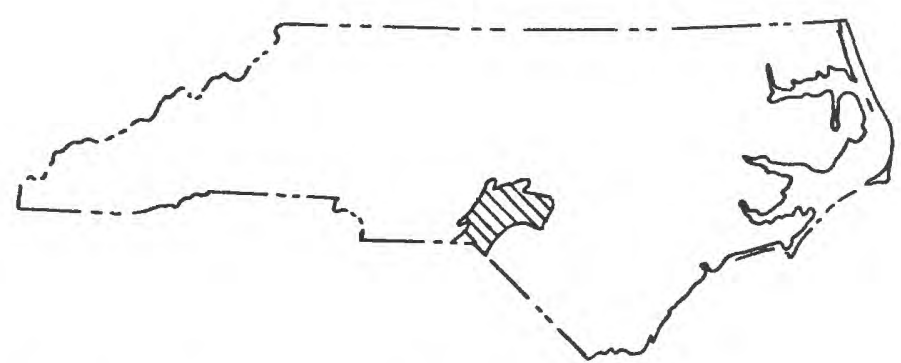

Project: (NC-83-005) Effects of Atmospheric Deposition on Water Quality of North Carolina Streams

Location: Southcentral North Carolina

Project Chief: J. Kent Crawford

Period of Project: $1983-92$

Cooperation: U. S. Environmental Protection Agency/Federal Research Program--USGS

Problem: The extent and severity of acid deposition in North Carolina and its effects on surface-water quality is poorly defined. Potential impacts from acid inputs include acidification of surface waters leading to degradation of the biological communities of streams, increased rates of corrosion in water-supply systems, mobilization of heavy metals, and threats to drinking-water supplies.

Objectives: To determine (1) the extent and severity of acid deposition in North Carolina, (2) whether the sources of acid in precipitation are local or distant, and (3) the impact of acid deposition on the water quality of North Carolina streams.

Approach: A calibrated watershed with measurements of the amount and quality of precipitation and stream discharge will be established in the Sandhills area of North Carolina. Stream-water quality will be correlated with precipitation quality to determine whether precipitation is influencing stream water. Additional water-quality sampling sites in the Sandhills will verify that the calibrated watershed is typical of streams in the area.

Progress: Routine monitoring at 1 calibrated watershed site, 5 peripheral stream sites, and 1 atmospheric deposition site in the Sandhills continued for the second year of a projected 10-year effort. The quality of data collected for the project was improved during the year by installing a v-notch weir at the Jordan Creek calibrated watershed site and by obtaining new $\mathrm{pH}$ electrodes which have a platinum internal wire and redox couple filling solution with doubleceramic junction design. Two audit samples were analyzed during the year and an audit of the precipitation sampling site was conducted. Several data-checking procedures were implemented, including ion balance calculations and theoretical conductivity calculations. 
Project: (NC-00-006) Flood Investigations

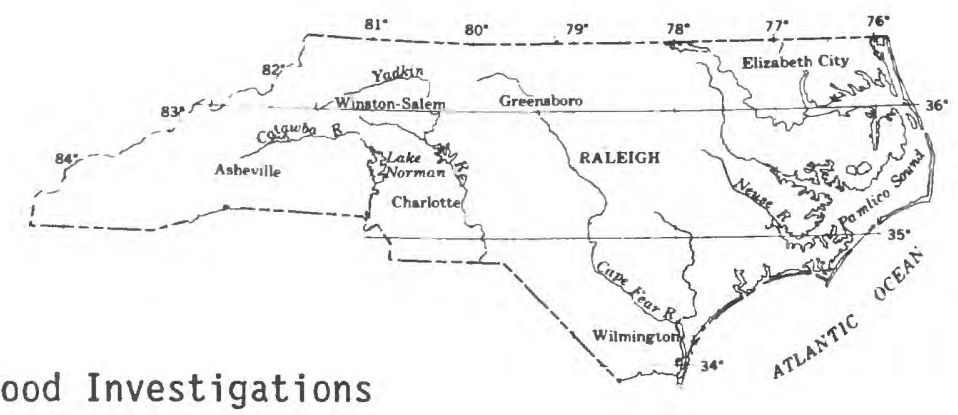

Location: Statewide

Project Chief: N. Macon Jackson, Jr.

Period of Project: Continuous since 1975

Cooperation: Federal Emergency Management Agency

Problem: The National Flood Insurance Act of 1968 and the Flood Disaster Protection Act of 1973 provides for the operation of a flood insurance program. The Federal Emergency Management Agency (FEMA) needs flood studies in selected areas for administration of the flood insurance program.

Objectives: To conduct the necessary hydrologic and hydraulic evaluations and studies of areas assigned by FEMA and to present the results in an appropriate format.

Approach: (1) To conduct the necessary evaluations or to conduct surveys by ground or photogrammetric methods; (2) to determine flood-discharge frequency relationships using local historical information, gaging station records, or other applicable information; and (3) to determine water-surface profiles by using step-backwater models, or other acceptable methods, and furnish the results in reports prepared to FEMA specifications.

Progress: Time and cost estimates for 9 flood insurance studies using less-than-detail metinods were approved and funded by the Federal Emergency Management Agency. Two studies are to be completed by December 31, 1985, with the remainder scheduled for completion by June 30, 1986. One study, Mars Hill, is in review, and field work is underway on 3 others. 


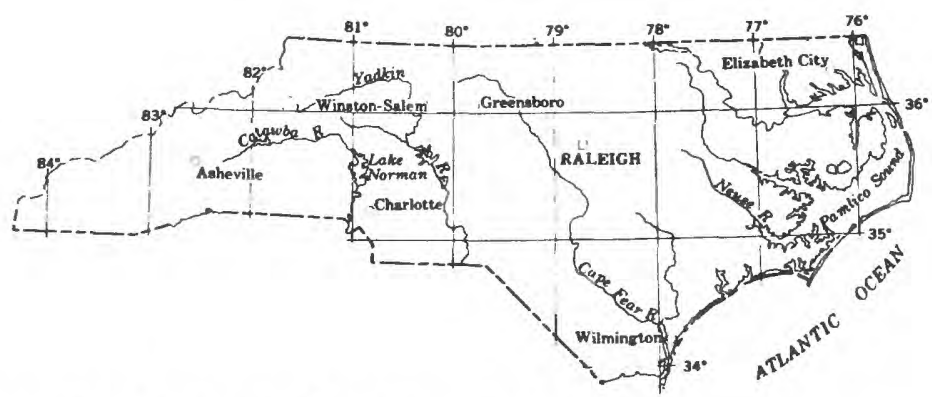

Project: (NC-00-007) Water-Use Data Collection Program in North Carolina

Location: Statewide

Project Chief: M. W. Treece, Jr.

Period of Project: Continuous since 1978

Cooperation: North Carolina Department of Natural Resources and Community Development (NRCD)

Problem: There is an increasing need for better data on quantities of water being used for all purposes in North Carolina. This information is essential in better long-range planning and water management.

Objectives: To develop and operate a coordinated water-use data collection, management, and reporting program which will be a waterresource planning and management tool for the State and will provide input into the national water-use data system.

Approach: A framework has been designed for the annual collection of water-use data in North Carolina that is required for the 1985 National Water-Use Report. Data collection and State Water-Use Data Systems (SWUDS) entry is underway for water-use data in the 12 categories of water use to be interfaced with the National Water-Use Data System (NWUDS) for the national report.

Progress: A water-use survey was conducted in the Roanoke-Dan and Chowan-Pasquotank River basins of North Carolina and Virginia. Data was collected for (1) agricultural irrigation, (2) self-supplied industrial, and (3) municipal water-uses in the survey area. The USGS assisted NRCD with the field collection and compilation of agricultural irrigation water-use data in the Roanoke and Chowan basins of North Carolina. The USGS also provided assistance with the compilation and quality assurance of the Virginia irrigation data and the industrial and municipal data for both North Carolina and Virginia. These data (about 2700 water users) were formatted and processed using modified SWUDS software; data summaries were generated to provide NRCD with information needed for a water-budget model. Field data collection has been completed for agricultural irrigation, self-supplied industrial, and municipal water uses in the Hiwassee and Little Tennessee River basins and is almost complete for the Tar River basin. 


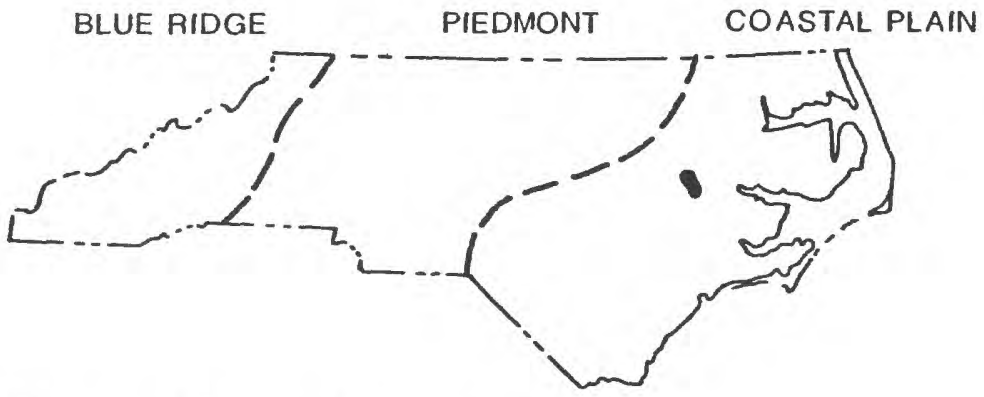

Project: (NC-76-053) Effects of Channelization on the Hydrology of Chicod Creek Watershed, North Carolina

Location: Northeastern North Carolina

Project Chief: Robert Mason

Period of Project: $1976-86$

Cooperation: U. S. Department of Agriculture--

Soil Conservation Service (SCS)

Problem: The characteristics of many small stream basins in eastern North Carolina have been changed by channel improvements designed to decrease flooding and improve drainage. The effects of channelization on areal hydrology have not been studied.

Objectives: To determine the effects of stream channelization on the hydrology of the Chicod Creek watershed including streamflow, surfacewater quality, and ground-water conditions.

Approach: Streamflow, water quality, and ground-water levels will be measured before, during, and after channelization activities. Streamflow and ground-water data will be analyzed by standard techniques including correlation with nearby longer-term datacollection stations. Water-quality studies will include the occurrence and transport of conventional chemical constituents, trace metals, pesticides, and organic materials. Sediment and bed material data will be collected at two in-stream sediment traps to determine efficiencies and other characteristics of traps.

Progress: Collection and processing of post-construction data continue. A meeting between Soil Conservation Service and U. S. Geological Survey personnel was held on May 21, 1985, to plan the schedule for completing the project. A second interim report contrasting hydrologic conditions in the Chicod Creek basin before and during channel modifications was released as Water Resources Investigations Report (WRIR) 84-4025. 
Project: SR 77-056 Appalachian Basin Waste-Storage Project

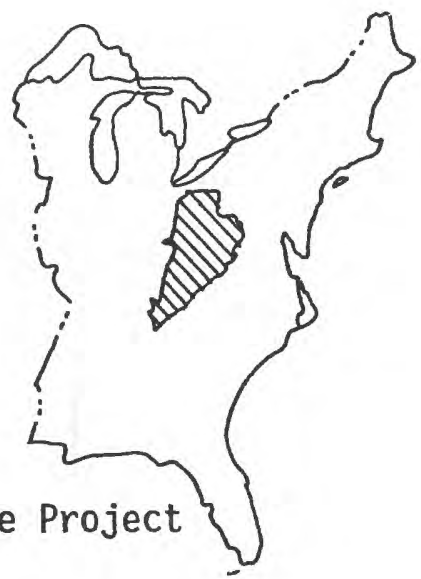

Location: Southern half of Appalachian basin

Project Chief: 0. B. Lloyd, Jr.

Period of Project: $1977-83$

\section{Cooperation: Federal}

Problem: The need exists to assess the physical potential for deepwell waste disposal in the southern half of the Appalachian basin, a region of geohydrologic complexity.

Objectives: To determine the presence, thickness, lateral extent, and composition of rocks that have potential, as reservoirs and reservoir seals, for the emplacement and storage of liquid waste in the deep subsurface in segments of the Appalachian basin by means of tectonicstructural-stratigraphic analysis.

Approach: Subsurface data obtained from previously drilled wells will be analyzed and coupled with an integration of areal tectonics, structure, and stratigraphy as they pertain to the location, manner of emplacement, and composition of depositional environments that have potential for waste storage.

Progress: Paleozoic sedimentary rocks in central and southern parts of the Appalachian bas in have been studied to determine their liquidwaste storage potential. Potential liquid-waste reservoirs and reservoir seals were described and mapped on the basis of the distribution of rock porosity. The areal extent, thickness of, and depth to the potential reservoirs and reservoir seals were delineated where the sedimentary rocks contain water with dissolved solids concentrations of 10,000 milligrams per liter or more (between about 1000 and 8000 feet below sea level). A report describing the results of the study has progressed through colleague review and is being prepared for the Director's approval and publication as a USGS Professional Paper. 


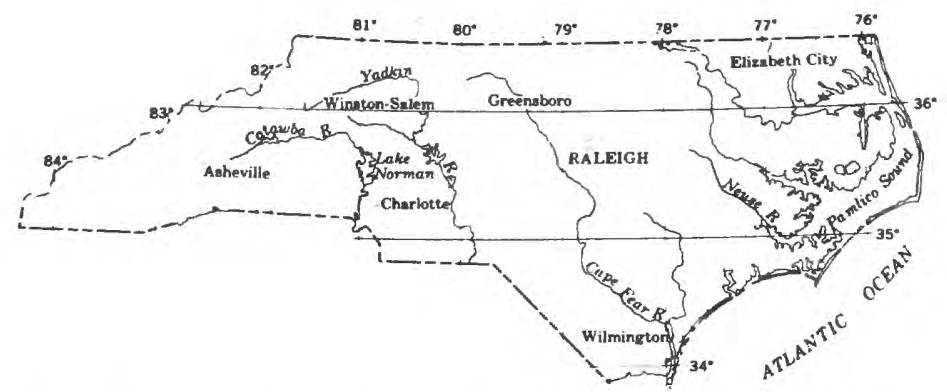

Project: (NC 78-063) Sediment Characteristics of Streams in North Carolina

\section{Location: Statewide}

Project Chief: Clyde E. Simmons

Period of Project: $1978-84$

Cooperation: North Carolina Department of Natural Resources and Community Development

Problem: Few data are available for determination of sediment characteristics of streams in North Carolina. The only areal study of fluvial sediment conducted in the State was made in 1969-73 by the USGS at gaging stations located within a 50-mile radius of Raleigh. The results of this study, which covers 15 percent of the land area in the State, are published in U. S. Geological Survey Water-Supply Paper 1798-0. Sediment characteristics of streams in the remaining 85 percent of the State are almost completely unknown. Data presented in WSP 1798-0 show that the sediment transport characteristics of the State's streams are highly variable from one region to another. This problem indicates that reliable estimates of sediment-transport characteristics can only be obtained by instituting a study of the remainder of the State.

Objectives: The objective of this investigation is to determine the sediment characteristics, such as sediment yield and effects of land use, of streams in North Carolina.

Approach: To minimize costs, the data-collection phase of this study was operated in conjunction with our ongoing surface-water streamgaging program. Samples for suspended-sediment concentrations and particle sizes were collected simultaneously with measurements of stream discharge. Approximately 150 gaging stations located throughout the State were selected as sampling points.

Primary emphasis is to define the average annual sediment yield at each station, approximate particle sizes of suspended materials at low and high flows, and sediment duration data. Other fluvial sediment data, such as bedload transport and gross erosion, will also be included in the study for selected basins and sites. 
Annual sediment yields will be determined using the flow-duration sediment-transport curve methods as daily values of streamflow are available for each sampling station. Computerized statistical methods will be used to determine effects of geology, land use, and other variables on stream sediment characteristics.

Progress: Final draft of the report was completed in November, and inter-District review was completed in mid-December. The report contains sediment-transport data, including loads and yields, for 7 forested sites, 7 forested sites impacted by highways, 84 rural sites, 22 urban sites, and 33 miscellaneous sites impacted by reservoirs, channelization, and other man-induced factors. The results of over 14,000 samples of suspended sediment, hundreds of particle-size analyses, and various other sediment data were used to develop equations for regionalizing suspended sediment characteristics and to characterize sediment transport by predominate 1 and use across the State. Bedload discharge, gross erosion, and sediment-delivery ratios were also determined for selected basins. The report shows that, Statewide, minimum yields occur in forested basins and range from 5 to 60 tons per square mile per year; ratios of average annual yields for forested, rural, and urban sites are approximately 1:3:10, respectively. The study focuses on larger stream basins with drainage areas primarily exceeding 5 square miles.

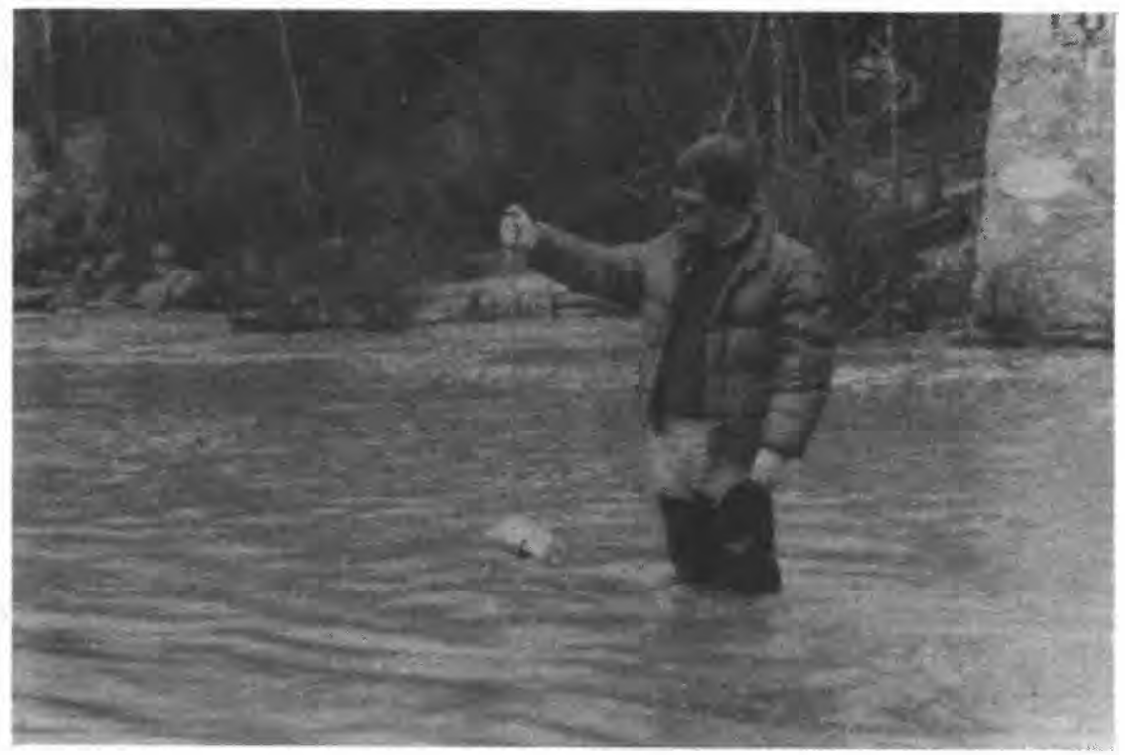

Collecting suspended sediment sample with a DH-48 sediment sampler. 


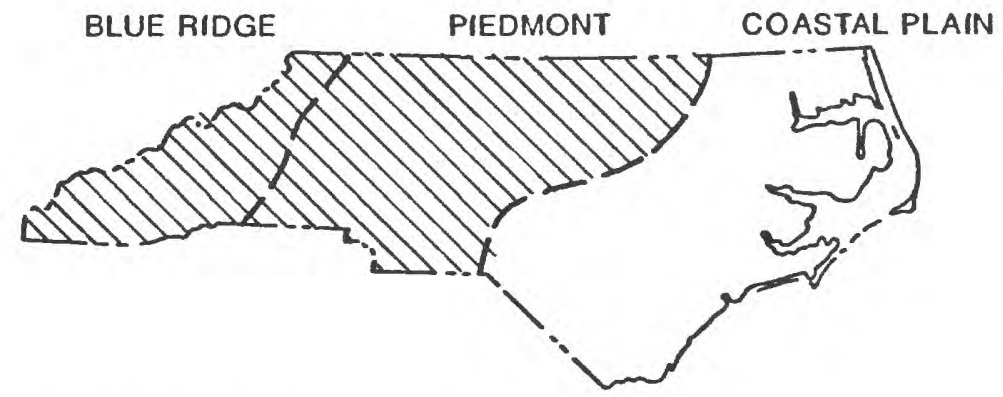

Project: NC 79-067 Ground-Water Development Potential in the Piedmont and Mountainous Areas of North Carolina

Location: Central and western North Carolina

Project Chief: Charles C. Daniel, III

Period of Project: $1979-84$

Cooperation: North Carolina Department of Natural Resources and Community Development (NRCD) and Town of Cary

Problem: The population of the Piedmont and mountain region is expected to double by 2020. The consequent need for new public and industrial water supplies will be met, in part, by new surface-water supplies; but, because of an increasing scarcity of good reservoir sites and increasing land acquisition and construction costs, groundwater supplies are becoming an increasingly attractive and costeffective alternative. However, water-bearing characteristics of rocks in the area are generally poor. To develop amounts of ground water needed for industrial or public water supplies requires locating wells in hard-to-find fracture zones.

Objectives: (1) To investigate and describe the most favorable hydrogeologic settings for developing large ground-water supplies; (2) to develop and describe techniques for locating favorable areas for large ground-water supplies, including locating fractures; and (3) to develop techniques for efficient development and management of large ground-water supplies in favorable areas, both as sole sources and as supplements to reservoir supplies.

Approach: Existing data pertinent to development of 1arge groundwater supplies will be compiled and techniques for locating fractures and for maximizing well yields will be investigated and tested.

Progress: A total of one and one-half years of pumping records from 12 wells was entered into computer files and analyzed to determine long-term yields, pumping times, and pumping rates. These data were compared to long-term recharge rates to gauge the effectiveness of the wells for extracting available recharge. A hydrogeologic unit map for the Piedmont and Blue Ridge provinces of North Carolina was compiled, and statistical analyses were performed on records from more than 6200 wells. 


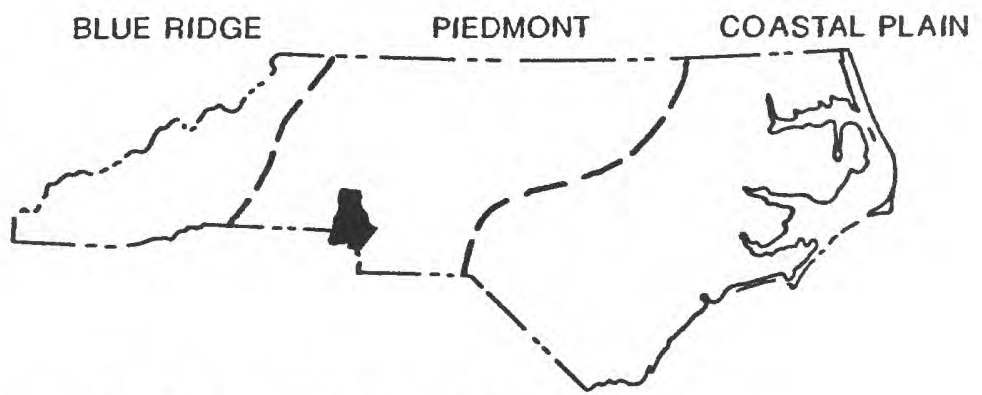

Project: (NC-80-068) Water Quality of Urban Areas in Charlotte and Mecklenburg County, North Carolina

Location: South Central North Carolina

Project Chief: William H. Eddins

Period of Project: $1979-86$

Cooperation: City of Charlotte and Mecklenburg County

Problem: Many outlying areas near the City of Charlotte are rapidly becoming urbanized. The potential for declining stream quality is particularly acute because of increasing quantities and types of effluents from point sources, such as municipal and industrial operations, and from non-point-sources, including runoff from streets, landfills, lawns, and industrial areas. Ground-water quality may be degraded by infiltrations of surface pollutants and leachate from landfills in immediate area of the source. Sediment is considered highly undesirable in urban streams because of the potential adverse affects that it may have on aquatic plant and animal development. However, sediment may be an important key to maintaining good water-quality conditions because of adsorption of chemical constituents and substances to suspended sediment.

Objectives: To investigate surface- and ground-water quality in 1 andfill and residential areas. The objectives in 1 andfill areas are to determine the movement and chemical-quality characteristics of ground water, to determine the effects of leachate on the ground and surface waters, and to evaluate the role of sediment on the chemical quality of surface water issuing from the 1 andfill areas. In residential areas, they are to evaluate the differences in chemical quality characteristics of streams in areas served by sanitary sewers and by individual septic tanks in residential areas.

Progress: Findings of a reconnaissance surface-water-quality study were released in Water Resources Investigations Report 84-4308 entitled, "Reconnaissance of Water-Quality Characteristics of Streams in the City of Charlotte and Mecklenburg County, North Carolina." 


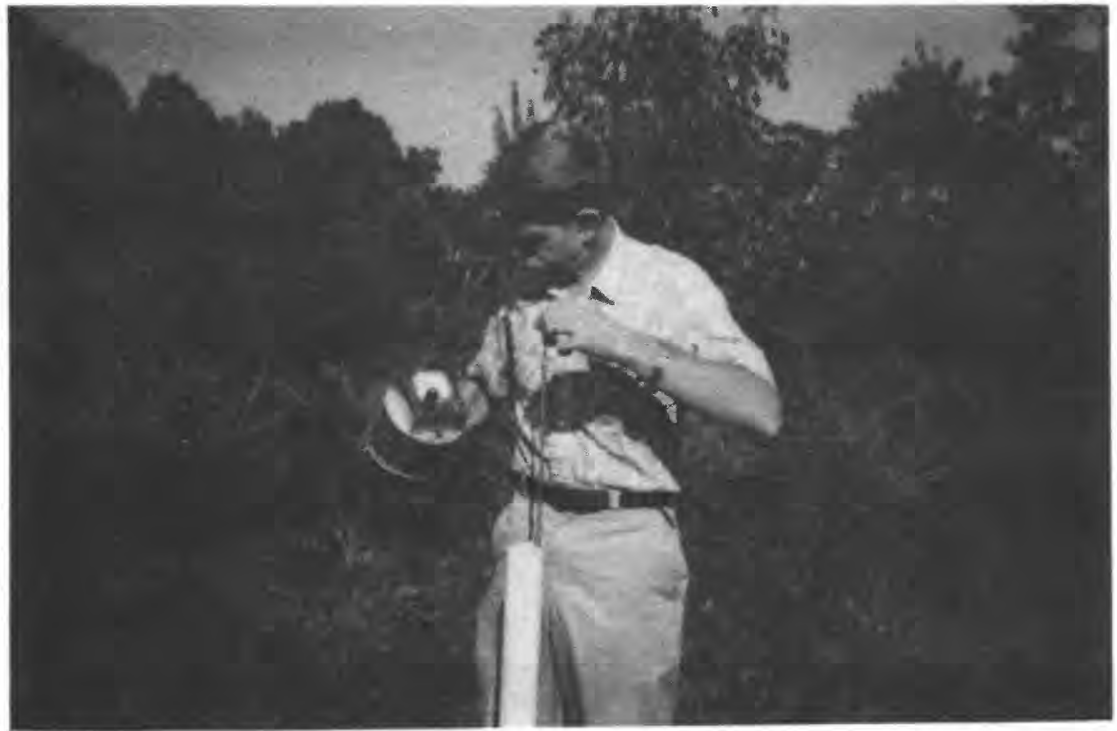

Taking ground-water level measure in observation we11 at landfill site for use in constructing water-table contour maps.

Samples from 24 observation wells, 10 residential wells, and 14 surface-water sites at 41 andfills in the Charlotte-Mecklenburg County area were analyzed for organic, inorganic, and biological constituents. Sample collection will be changed from a quarterly to a semi-annual or annual schedule at the sites that show essentially no traces of pollutants. Continuous temperature and conductance records were collected at 4 other sites.

Four test wells and two monitor wells were drilled at the York Road and Harrisburg Road landfills. The two Harrisburg Road monitor wells will be used to determine the effects landfill operations have on water-table depth and vertical water movement. A nest of additional observation wells will be drilled to varying depths at York Road and at Harrisburg Road to determine the rate and direction of movement of pollutants from these landfills. Borehole geophysical logs were collected from 12 wells in the York Road and Harrisburg Road landfills to obtain more data on the local hydrogeological regime. 


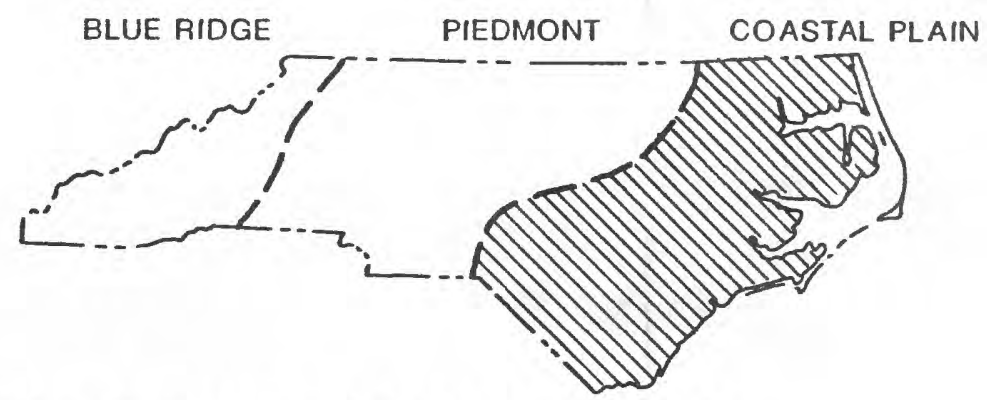

Project: (NC-80-070) Urban Hydrology of the Coastal Plain

Location: Eastern North Carolina (Coastal Plain province)

Project Chief: H. C. Gunter

Period of Project: $1980-86$

Cooperation: North Carolina Department of Transportation

Problem: Urbanized areas within the Coastal Plain province are experiencing problems of drainage and damage resulting from flooding of small streams. Drainage problems include design of small bridges, culverts, storm sewers, and stream-channel treatment. Due to urban development in the basins and flood-plain encroachment, many areas, which formerly were rarely inundated, are now flooded with increasing frequency.

Objectives: Hydrologic data before and after urban development are usually unavailable. Therefore, rainfal1-runoff data from watersheds that are in the same region but in different stages of urbanization will be used for analysis and comparison to: (1) evaluate quantitatively the flood potential of urban watersheds, and (2) derive usable relationships for determining peak discharges from small urban watersheds by evaluating the effects and relation of various natural and urban characteristics.

Approach: Continuous rainfall and runoff data will be recorded concurrently at selected sites. The recorded data will be used in conjunction with long-term rainfall to generate expected long-term runoff data. The generated data and observed short-term data along with observed long-term data in the region will be used in several linear regression models for determination of relationship to basin characteristics for which physical factors and changes can be evaluated. Significant factors will be combined in formulas for peak discharges having selected recurrence intervals.

Progress: A data base consisting of floods for selected recurrence intervals and selected basin characteristics was established for regional flood analysis. Using this data base, regional relations for computing the 2-, 5-, 10-, 25-, 50-, 100-, and 500-year floods for streams in North Carolina were updated. Calibration of the rainfallrunoff model for stations in the urban areas of the Coastal Plain has been completed. 


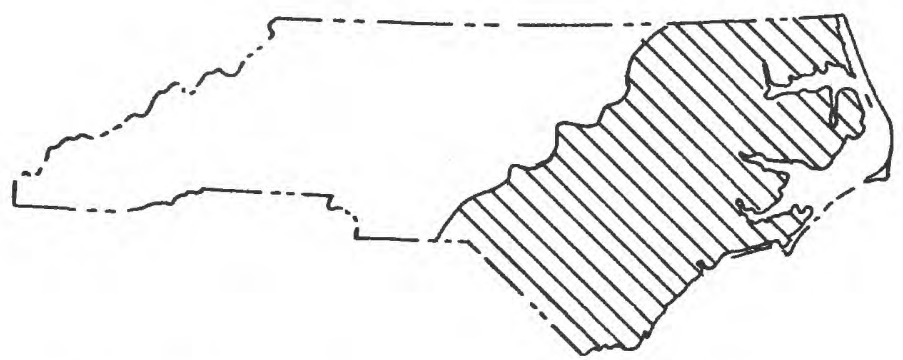

Project: (NC 80-071) Coastal Plain Aquifer Study--Regional Aquifer Systems Analysis (RASA)

Location: Eastern North Carolina

Project Chief: Gerald L. Giese

Period of Project: $1979-86$

\section{Cooperation: Federal}

Problem: Ground water is the major source of water for every type of freshwater use in the North Carolina Coastal Plain. Withdrawal of water from several major aquifer units at rates in excess of recharge is now taking place, resulting in extensive cones of depression and the threat of saltwater intrusion into previously fresh aquifers in several areas.

Objectives: To develop the capability to make predictive evaluations of the North Carolina Coastal Plain aquifer system, which can best be achieved by means of a digital computer model designed to simulate the response of the multilayered aquifer system to pumping and other stresses. To accomplish the major objective, several preliminary objectives must be achieved. These are: (1) to define the geology, hydrology, and geochemistry of the aquifer system; (2) to define, using historical data, the ground-water flow system, natural groundwater quality, and position of fresh-salt-water interface before extensive ground-water withdrawals began; and (3) to develop a computerized data-base system to store data for use in model development.

Approach: (1) Compile and evaluate existing geologic, hydrologic, and geochemical data; (2) develop contour maps of hydrogeologic, hydrologic, and geochemical parameters and interpolate from maps values of parameters at node points in a digital-model grid system; (3) enter node values in computerized data management system; (4) develop preliminary steady-state and transient models; and (5) on basis of preliminary model results, collect data needed to refine models.

Progress: A draft of the report on the hydrogeologic framework of the North Carolina Coastal Plain is in colleague review. Calibration of the three-dimensional ground-water flow model of the North Carolina Coastal Plain was completed and a sensitivity analysis was performed. A draft of the report describing the flow model is about 50 percent complete. 


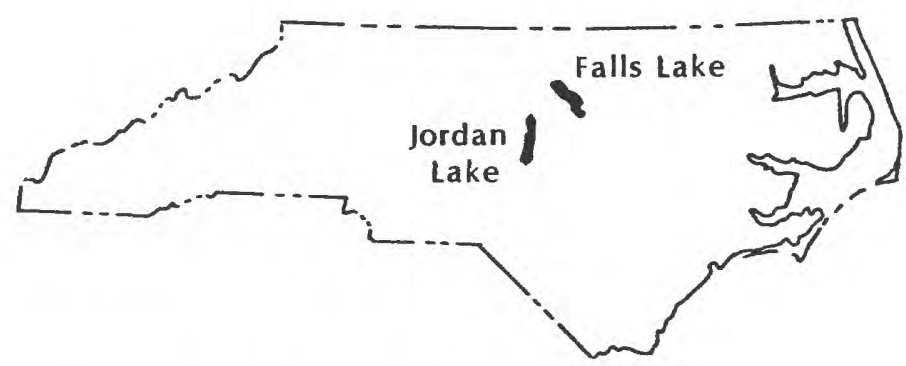

Project: (NC 83-073) Water Quality of Inflow to Falls and Jordan Lakes, North Carolina

Location: Northern North Carolina

Project Chief: Ronald G. Garrett

Period of Project: $1982-86$

Cooperation: U. S. Army Corps of Engineers

Problem: The filling of the 13,900-acre Jordan Lake was completed in February 1982. The filling of the 12,500-acre Falls Lake was completed in June 1983. Few data are available on the quality of inflow to the lakes; however, several cities plan to use the lakes for public water supply. Chemical-quality characteristics of inflow need to be determined for current and future development conditions.

Objectives: To collect hydrologic data for evaluating chemicalquality characteristics of inflow to major reservoirs under existing and future development conditions.

Approach: Six sites on major streams flowing into Falls Lake and four sites flowing into Jordan Lake were selected by the cooperator as data collection stations. Continuous stage, temperature, and specific conductance are to be collected at each site. Concentrations of major constituents, nutrients, trace metals, and suspended sediment are to be determined from approximately 12 stream samples per year. Values of alkalinity, $\mathrm{pH}$, dissolved oxygen, and specific conductance are to be determined at time of sample collection.

Progress: Collection and processing of water-quality data at the Falls project stations were performed on schedule. The water-quality data collection for the sites located at Jordan Lake was completed and activities discontinued during November 1985. Although not a part of this project, various cooperators have agreed to fund the continuation of streamflow operations at the Jordan Lake sites. Discharge data and laboratory analyses were released to the cooperator on a quarterly basis. Preliminary computations of nitrogen and phosphorus influx into the lakes during 1985 were transmitted to the cooperator. 


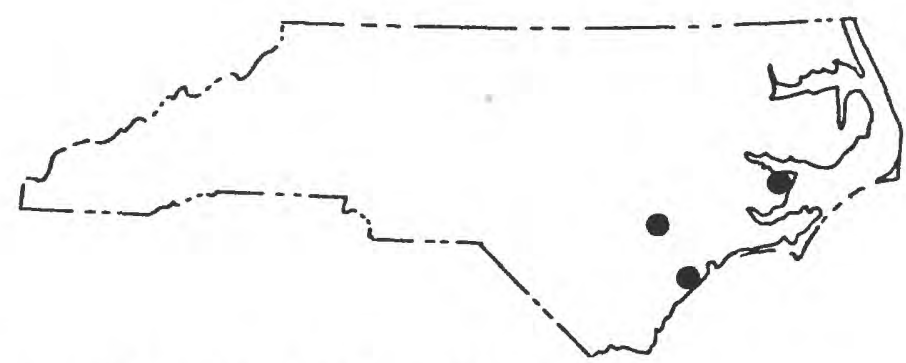

Project: (NC 83-074) Effects of Stream Restoration on Hydrology of the Grove Creek Watershed near Kenansville, North Carolina

Location: Southeast Coastal North Carolina

Project Chief: Timothy C. Stamey

Period of Project: $1982-87$

Cooperation: North Carolina Department of Human Resources (DHR)

Problem: Grove Creek, in its present sluggish and swampy condition, and the tidal marshes at Hobucken and West Onslow Beach are breeding grounds for mosquitoes. The State needs documentation of hydrologic changes that occur as the result of their stream restoration technique at Grove Creek and open marsh water-management techniques to be used at Hobucken and West Onslow Beach, which are designed to drain or allow access of forage fish to the mosquito breeding pools and thus reduce mosquito populations. Collection of data are needed for defining the hydrologic changes caused by these techniques.

Objectives: To define the hydrology of Grove Creek, Hobucken, and West Onslow Beach before, during, and after the channel modifications and excavations, with emphasis on the effects of the drainage and water-management techniques used at each site, on increasing drainage from the shallow breeding pools.

Approach: Eight data collection sites were constructed in the Grove Creek basin, including one site on Nahunga Creek, the adjacent control basin. Streamflow data will be collected at each site on a continuous or periodic basis. Continuous and periodic ground-water data will be collected from 25 shallow wells. Limited water-quality data will be obtained from 5 sites. A total of 6 continuous recording surfacewater gages, 8 recording, and 16 periodic water table wells will be constructed at Hobucken and West Onslow Beach. Entomologic data will be collected by private contractor to determine the effects of the hydrologic changes on mosquito populations.

Progress: Data collection continues. An interpretive report, "Frequency and duration of flooding of Grove Creek near Kenansville, North Carolina, for present and restored channel conditions," was completed for an 8-mile reach on Grove Creek. 


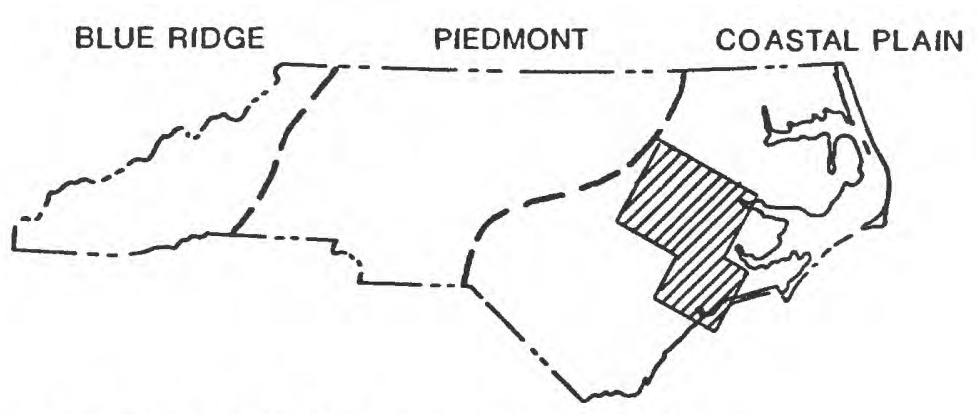

Project: (NC 83-075) Central Coastal Plain Aquifer Study

Location: East-Central North Carolina

Project Chief: Maurice D. Winner, Jr.

Period of Project: $1983-88$

Cooperation: North Carolina Department of Natural Resources

and Community Development (NRCD); the cities

and towns of Ayden, Farmville, Kinston, La Grange,

New Bern, Pinetops, Snow Hi11, Stantonsburg, and

Jacksonville; Greene, Jones, and Onslow Counties;

Greenville Utilities; and North Lenoir Water Corporation

Problem: Increasingly heavy ground water use by the City of Kinston and surrounding communities and industries since World War II has stressed the Cretaceous aquifer system, producing water level declines of several feet per year. NRCD expects this area to be their next Capacity-Use Area, the second in the State, where strict management of water withdrawals may be imposed.

Objectives: (1) To evaluate the ground-water supply potential of the central Coastal Plain and, (2) to make quantitative predictive evaluations of the effects of al ternative ground-water development schemes, especially with regard to maximum development potential, declines in water levels, and saltwater intrusion.

Approach: (1) Develop a hydrogeologic framework for the study area. (2) Incorporate the framework into a digital computer model of the ground-water flow-system. (3) Using the model, simulate the response of the flow system to pumping stresses and evaluate the ground-water supply potential of the Central Coastal Plain study area. (4) Some test-well drilling and observation-well construction will be done.

Progress: Data for about 60 aquifer tests were reviewed and analyzed for aquifer transmissivity values. A successful trial run of the central Coastal Plain steady-state model was made using transformed parameters from the RASA model of the N. C. Coastal P1ain ground-water flow system (see project NC 80-071). Two test holes and three observation wells were completed by NRCD as part of their contribution to the study. A map report has been prepared that describes the altitude of the basement-rock surface underlying the study area. 


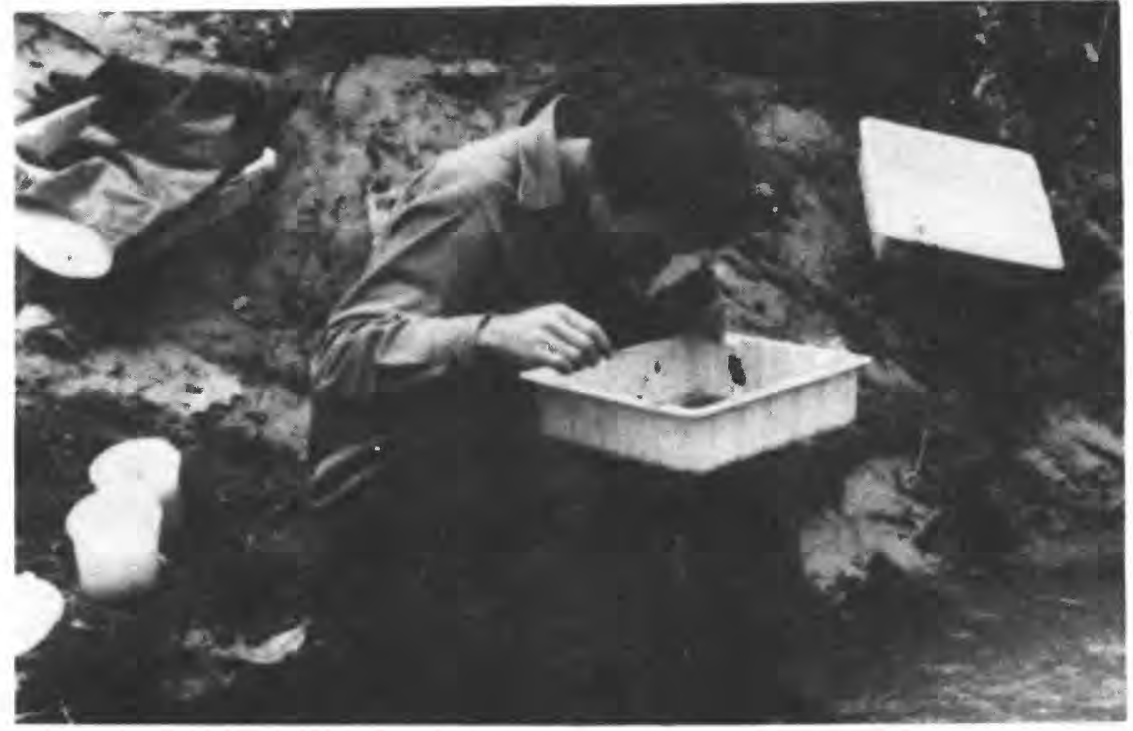

Dave Lenat (NRCD) collecting aquatic macroinvertebrates for determining biological health of a stream.
Project: (NC 84-076)

Land Use Effects on

Stream Biology

Location: North-

Central North

Carolina (Piedmont)

Project Chief:

J. Kent Crawford

Period of Project: January 1984 to March 1986

Cooperation: North Carolina Department of Natural Resources and Community Development (NRCD)

Problem: Sediment, and its effects on streams, is considered to be the most widespread water-quality problem in North Carolina. The effects include: (1) siltation of reservoirs; (2) destruction of habitats for stream-benthic organisms and spawning fish; (3) reduction of light penetration; (4) impairment of aesthetic qualities of water courses; and (5) chemical alteration of water.

Objectives: To examine the effects of three land uses (forests, agriculture, and urban) on stream environments by: (1) monitoring the chemical characteristics of the water column, including transport in solution and transport associated with suspended sediment; (2) monitoring the chemical and physical characteristics of bed material, including both sediments and interstitial water; (3) characterizing the aquatic invertebrate communities of each of the study streams; and (4) relating biotic degradation found during the study to water quality, sediment quality, and land-use activities.

Approach: Three streams, as nearly equal in drainage area, volume of discharge, and soil type as possible, will be selected for study so that one stream drains predominately forested land, one drains predominately urban land, and one drains predominately agricultural land. One station will be established on each stream to monitor stream discharge, water chemistry, sediment chemistry, and the biological community.

Progress: Data collection continued but was briefly interrupted when NRCD suspended operations on the project from February through June 1985. All biological and water-column sampling has been accomplished except for additional suspended sediment sampling at Smith Creek (the forested site) that is needed for calibration of the automatic sampling device. Efforts to define the suspended sediment vs. discharge relation at Smith Creek continue. 


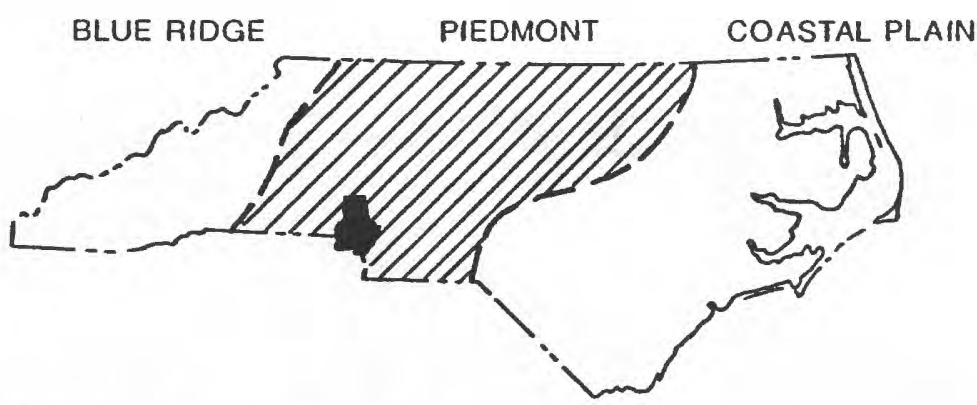

Project: (NC 84-077) Effects of Land Use on Ground-Water Quality in the Piedmont Province, North Carolina

Location: Piedmont Province of North Carolina

Project Chief: Douglas A. Harned

Period of Project: $1984-86$

\section{Cooperation: Federal}

Problem: Ground-water quality is inadequately defined in the Piedmont of North Carolina. Little is known about the variability of groundwater quality, or the nature and extent of contamination of ground water in the Piedmont.

Objectives: To study the quality of ground water in the regolith and fractured rock ground-water system, stressing the relation between water quality and land use.

Approach: Assess data from existing sources on ground-water quality in the Piedmont of North Carolina and study areas with representative land uses. Statistical correlation between ground-water quality and land use will allow regionalization of results.

Progress: Compilation of the data file was completed and editing of the file begun. Evaluation of the gas-chromatograph flame-ionizationdetector scans and Neutron-activation scans of baseflow samples from proposed monitoring sites in Mecklenburg County show organic and trace-metal contamination at the old-industrial and downtown-urban land-use categories. The Phase I report was completed and prepared for colleague review. Analysis of variance of the data showed that land use, soil type, and rock type all significantly affect groundwater quality for many constituents. Project canceled February 1986. 


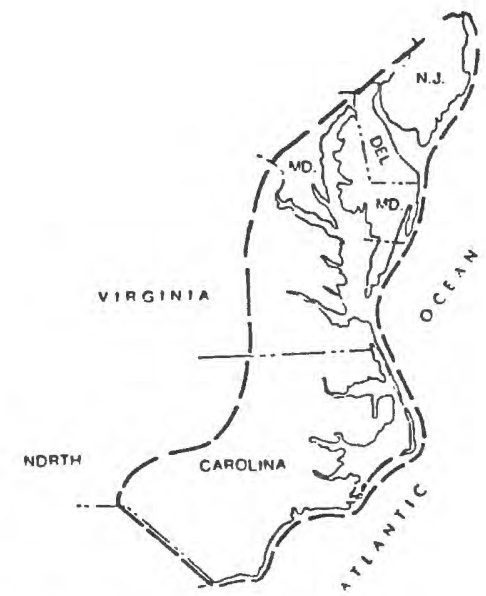

Project: NC 84-078 North Atlantic Coastal Plain Hydrology and

its Relation to Disposal of Nuclear Waste

in Buried Crystalline Rocks

Location: Coastal Plain areas of States from New Jersey to North Carolina

Project Chief: 0 . B. Lloyd, Jr.

Period of Project: 1983-85

Cooperation: Federal

Problem: High-level radioactive wastes need a permanent repository for disposal that wi11: (1) isolate the wastes from the accessible environment for a long time and protect the wastes from human intrusion, and (2) minimize migration of wastes and be an environment in which transport is predictable in both time and space.

Objectives: To summarize the hydrology of the North Atlantic Coastal PTain and determine within the limits of the available data (1) if suitable geohydrologic characteristics exist for isolation of highlevel radioactive waste in buried crystalline rocks, and (2) if sufficient data are available to define areas where the buried crystalline-rock concept might be applied in any subsequent sitescreening program.

Approach: Existing data will be compiled and reviewed. Appropriate maps and cross sections will be prepared to define the geohydrologic conditions, and a report, summarizing the findings, will be prepared.

Progress: The sedimentary rocks in parts of the Northern Atlantic Coastal Plain have been studied to make a preliminary evaluation of the suitability of the geohydrology to the disposal of high-level radioactive wastes in crystalline rocks that lie beneath the sediments. Thickness of the saline-water-bearing sediments, watertransmitting capacity of the two lowermost aquifers, effects of ground-water withdrawals from the two lowermost aquifers on lateral ground-water movement, and thickness of the two lowermost confining beds were used to make the preliminary evaluations. A report by Lloyd, Larson, and Davis describing the results of the study has been pubi ished as Water-Resources Investigations Report 85-4146. 


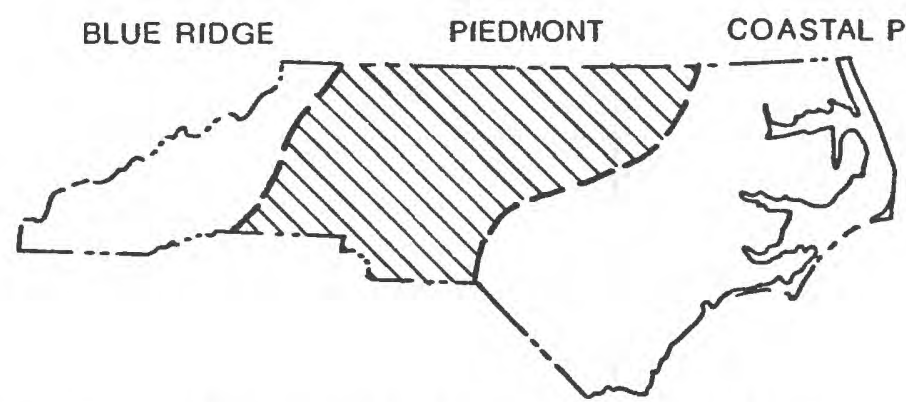

Project: (NC 84-079) Modeling of Ground-Water Movement Within the Combined Regolith-Fractured-Rock Aquifer System of the Central Piedmont Province, North Carolina

Location: Central North Carolina

Project Chief: Charles C. Daniel, III

Period of Project: $1983-85$

Cooperation: North Carolina Department of Natural Resources and Community Development (NRCD)

Problem: Ground-water flow in fractured rocks and the influence of fractured properties is poorly understood. The movement of entrained substances, particularly the hazardous compounds in fractured rocks, is of special concern because of the widespread use of ground water from fractured-rock aquifers as potable supplies and because contaminated ground water will ultimately flow to some wells and discharge to surface waters.

Objectives: To describe and evaluate the characteristics of groundwater flow in relation to properties of bedrock, properties of fractures, and properties of the overlying regolith in order to develop digital models that can be used to predict the movement of ground water through the bedrock-regolith system. The models will be sufficiently detailed to account for the movement of water and leachate from landfills and waste sites into the ground-water system.

Approach: Wells will be drilled into the bedrock and the regolith in two test sites. Infiltration rates will be determined. When feasible, core samples will be collected and analyzed. Field studies and geophysical logs will be used to determine aquifer properties. Water budgets, incorporating rainfal1, infiltration, evapotranspiration, and discharge to streams will be used to check the ground-water circulation model(s).

Progress: Geophysical surveying field work was performed at the Greensboro-Highpoint Regional Airport research site. Computer programs for processing the data were obtained and entered into the computer, and copies of the geophysical data from surveys were obtained from the contractor. The project was suspended effective January 15, 1985. 


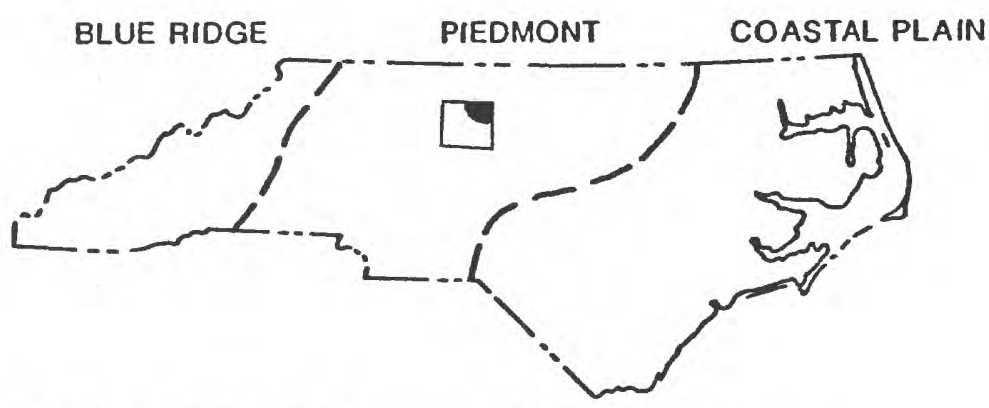

Project: (NC 85-081) Effects of Land-Management Practices on Sediment and Chemical Transport in Guilford County, North Carolina

Location: Central North Carolina

Project Chief: C. L. Hill

Period of Project: $1984-90$

Cooperation: Guilford County Soil and Water Conservation District and U. S. Soil Conservation Service

Problem: Extensive farming in the southeastern states results in agricultural runoff, one of the major nonpoint sources of pollution from agricultural lands. Agricultural runoff is a major contributor of sediment, nutrients, and toxics to our water resources, yet its full impact is unknown.

Objectives: (1) To evaluate and quantify fluvial sediment and associated chemical constituents transported via surface water from basins chosen according to land-management practices. (2) To quantify the dispersion and movement of selected chemical constituents from distinct soil horizons in the unsaturated zone and from discrete zones of the unconfined aquifer.

Approach: Four small basins have been selected. One is forested and will remain that way for the duration of the project to characterize background conditions. Two are heavily farmed, one using Best Management Practices (BMP's) and the other using poor land-use methods. Existing hydrologic and chemical characteristics will be compared over a 2-3 year period. The fourth basin has mixed-rural 1 and uses. It will be characterized during the initial 2-3 year period and then BMP's will be implemented for a 2-3 year follow-up period.

Progress: Each 6-acre basin has been equipped with a runoff station with stage recorder and automatic water sampler, nine ground-water wells, and 18 lysimeters. Rainfall is being monitored with a recorder and will be analyzed periodically. SCS did a soil survey and has run levels to the wells, tying them into mean sea level. Water-quality data have been collected at two of the wells, irrigation water, two perennial streams, two runoff sites, and various lysimeters. SCS is monitoring chemical application and irrigation amounts. 


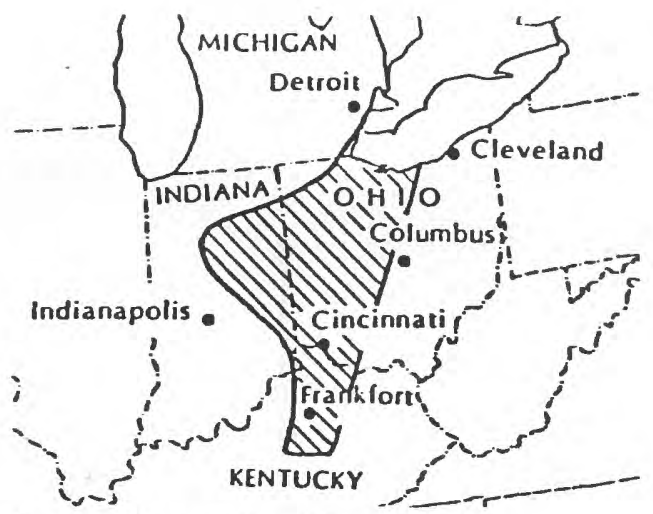

Project: NC 85-082 Evaluation of the Hydrogeology in the Cincinnati Arch Region with Regard to Isolation of Nuclear Wastes in Buried Crystalline Rocks

Location: Eastern Indiana, north-central Kentucky, and western Ohio

Project Chief: 0. B. Lloyd, Jr.

Period of Project: $1984-86$

\section{Cooperation: Federal}

Problem: High-level radioactive wastes need a permanent repository for disposal that will: (1) isolate the wastes from accessible environment for a long period of time and protect the wastes from human intrusion, and (2) minimize migration of wastes and be an environment in which transport is predictable in both time and space.

Objectives: To summarize the hydrology of the Paleozoic sediments in the Cincinnati arch area and determine (1) if suitable geohydrologic characteristics exist for isolation of high-level radioactive waste in buried crystalline rocks that may underlie the area, and (2) if sufficient data are available to define areas where the buried crystalline-rock concept might be applied in any subsequent sitescreening program.

Approach: Existing data will be compiled and reviewed. Appropriate maps and cross sections will be prepared to define the geohydrologic conditions. A report that summarizes the findings will be prepared.

Progress: The Paleozoic sedimentary rocks in the Cincinnati arch area are being studied to make a preliminary evaluation of the suitability of the hydrogeology to the disposal of high-level radioactive wastes in crystalline rocks that lie beneath the area. Available geologic and hydrologic data are being collected and analyzed and hydrogeologic maps and cross sections are being prepared. The data are being used to determine (1) the depth to, thickness, extent, water-transmitting capacity, hydraulic head, and ground-water quality of the Mount Simon Sandstone (the formation that lies directly on the crystalline basement rock) and (2) the thickness, extent, continuity, and watertransmitting capacity of confining beds that occur between the top of the Mount Simon Sandstone and the bottom of the Knox Dolomite. 

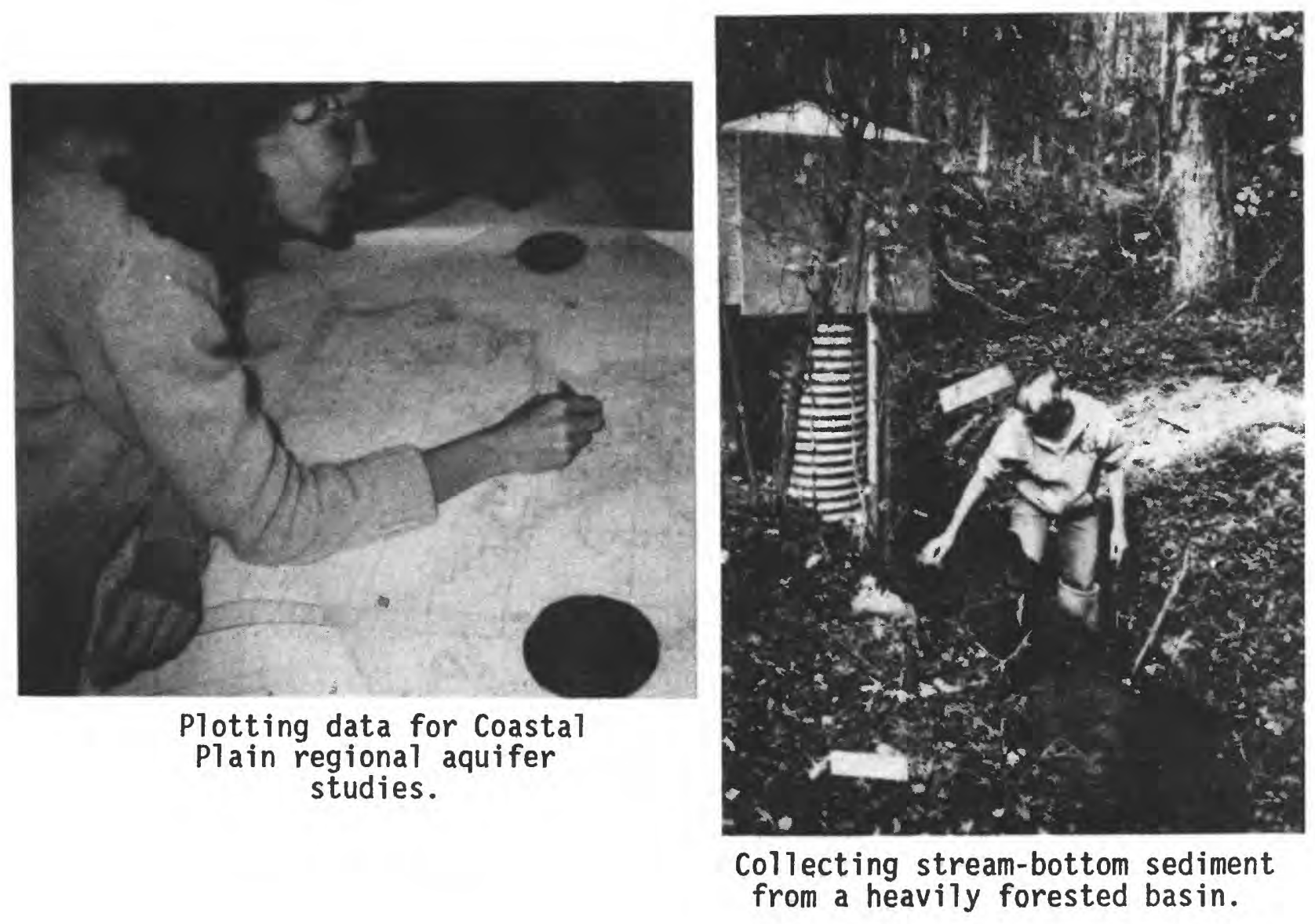

Plotting data for Coastal

$\mathrm{Plain}$ regional aquifer studies.

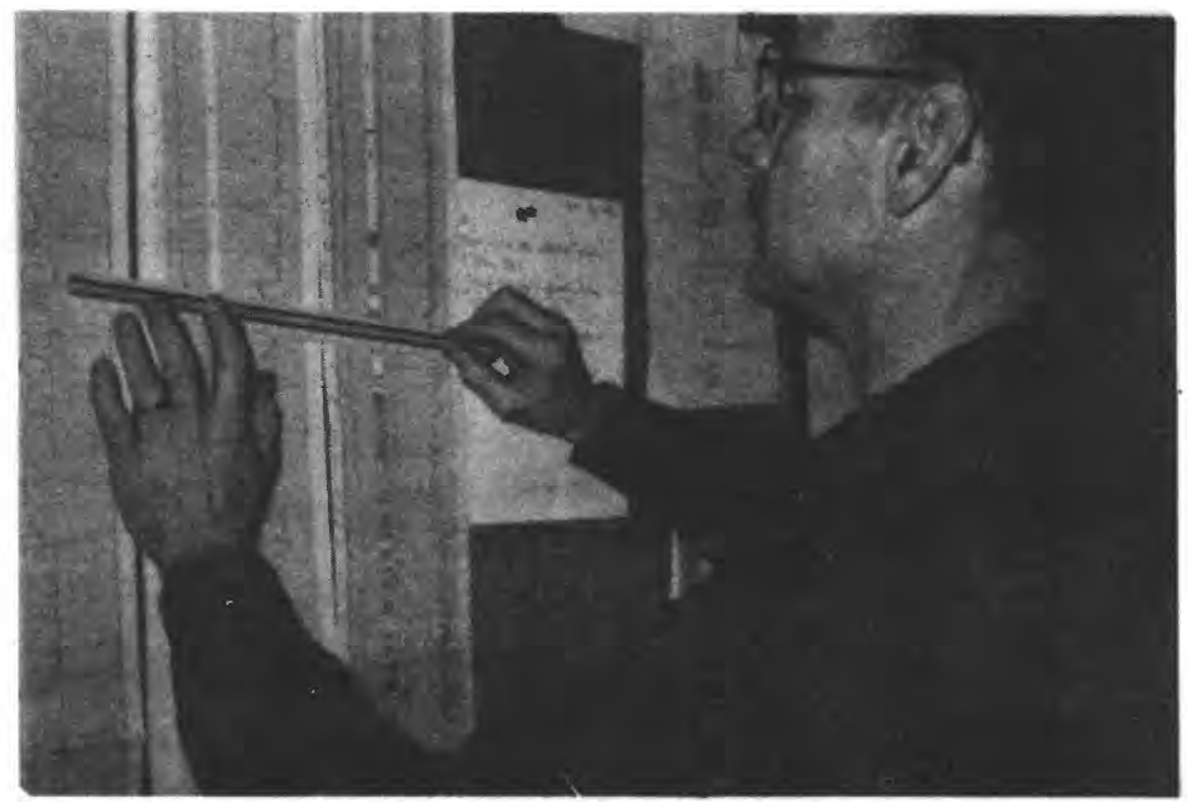

Using borehole geophysical logs to correlate hydrogeologic units in Coastal Plain sediments. 


\section{SELECTED LITERATURE ON WATER RESOURCES}

Selected reports on water resources in North Carolina are listed on the following pages; many of the reports are available for public inspection at one of the offices shown on figure 3 , as we 17 as at larger public and university libraries in the state. The lists include: (1) U. S. Geological Survey publications that (a) can be purchased or obtained from the Geological Survey; and (b) are released either to the open file or as water-resources investigations reports and can be inspected at specific offices; (2) reports from the cooperating agencies; and (3) other publications such as technical journals and publications prepared by the District staff. New reports published or released by the Geological Survey are announced monthly in "New Publications of the Geological Survey." Subscription to the monthly list is available upon request to the U. S. Geological Survey, 582 National Center, Reston, VA 22092.

Publications of the U. S. Geological Survey, including professional papers, water-supply papers, and bulletins are sold ; by the Eastern Distribution Branch, U. S. Geological Survey, 604 South Pickett Street, Alexandria, VA 22304 (authorized agent of the Superintendent of Documents, Government Printing office). Single copies of circulars still in print are available upon request to the U. S. Geological Survey, Eastern Distribution Branch, 604 South Pickett Street, Alexandria, VA 22304. Water-resources investigations folders (similar to this one) for each of the 50 states and Puerto Rico are also available upon request. Hydrologic investigations atlases, hydrologic unit maps, and other maps pertaining to North Carolina are sold by the Eastern Distribution Branch, U. S. Geological Survey, 1200 South Eads Street, Arlington, VA 22202.

Open-file reports are available for inspection in the Raleigh, North Carolina, and Reston, Virginia, offices of the U. S. Geological Survey; copies ordinarily are not reproduced and distributed in quantity. Most numbered open-file reports may be purchased from the Open-File Services Section (OFSS), Western Distribution Branch, U. S. Geological Survey, Box 25425, Federal Center, Denver, C0 80225. Information on the availability of the unnumbered reports may be obtained from the District Chief, U. S. Geological Survey, Water Resources Division, at the Raleigh address shown on the cover of this booklet.

Listed reports prepared by the U. S. Geological Survey in cooperation with, and published by, State or local agencies may be inspected or obtained from the cooperating agency or the $U$. S. Geological Survey office in Raleigh, North Carolina. In addition, many of these are available for inspection at the larger public and university libraries in the State. 
Records of streamflow, ground-water levels, and quality of water have been published for many years in the Geological Survey WaterSupply Paper series. Beginning with the 1975 water year, however, these series were replaced by a new publication series, U. S. Geological Survey Water-Data Reports. This new report series is published annually and combines under one cover for each State: streamflow data, water-quality data for surface water and ground water, and ground-water level data from the basic network of observation wells. For North Carolina, the title is "Water-Resources Data for North Carolina--Water Year (date): U. S. Geological Survey Water-Data Report NC-(date)-1." Other publication series of general interest also are explained below. Further information on these publications can be obtained from the District Chief, Water Resources Division, at the Raleigh address shown on the cover of this booklet.

The U. S. Geological Survey Yearbook provides a comprehensive description of the Federal Government's largest earth-science agency. Summaries of research in progress and results of completed investigations are published each fiscal year in the professional paper series "Geological Survey Research." Both publication series are sold ; by the Eastern Distribution Branch, U. S. Geological Survey, 604 South Pickett Street, Alexandria, VA 22304.

A pamphlet entitled, "Geologic and water-supply reports and maps for North Carol ina," is available upon request to the U. S. Geological Survey, 420 National Center, Reston, VA 22092.

\section{Surface Water}

Data Reports

Streamflow data

Records of daily flow of streams are given in the Water-Supply
Paper series of the Geological Survey, "Surface-Water Supply of the
United States." Before 1961, this was an annual series in three
parts, Part 2-A contained data for streams draining to the Atlantic
Ocean, Part 3-A contained data for streams in the New River basin, and
Part 3-B contained data for streams in the Tennessee River basin. For
the period 1961-70, 5-year compilations were published containing data
for North Carolina. The parts for this period are Part 2, Volume 1,
containing data for streams draining to the Atlantic Ocean; Part 3,
Volume 2, containing data for streams in the New River basin; and Part
3 , Volume 4, containing data for streams in the Tennessee River basin.
Also, from 1961 through 1974, daily streamflow records were released
annually in a single open-file report covering the entire State. As
of 1975, streamflow data are released in the annual publication "Water
Resources Data for North Carolina, Water Year




\section{Floods}

The U. S. Geological Survey has outlined flood-prone areas on topographic maps as part of a recent nationwide Federal program for managing flood losses. In North Carolina, 480 flood-prone area maps have been completed. These maps are available from the District Chief, Water Resources Division, U. S. Geological Survey, P. 0. Box 2857, Raleigh, NC 27602. Additional basic-data reports pertaining to surface-water resources are listed below:

Meikle, R. L., 1983, Drainage areas of selected sites on North Carolina streams: U. S. Geological Survey OpenFile Report 83-211.

Thomas, N. 0., 1973, Summaries of streamflow records: North Carolina Department of Natural and Economic Resources.

Thomas, N. 0., and Bonham, W. G., 1976, Annual maximum peak stages and discharges of North Carolina streams: North Carolina Department of Natural and Economic Resources.

Thomas, N. 0., and Jackson, N. M., Jr., 1981, Manual for leveling at gaging stations in North Carolina: U. S. Geological Survey Open-File Report 81-1104.

U. S. Geological Survey, 1961-64, Surface-water records of North Carolina.

U. S. Geological Survey, 1965-74, Water-resources data for North Carolina--Part 1, Surface-water records.

\footnotetext{
1975-80, Water-resources data for North Carolina--Water Year NCU. S. Geological Survey Water-Data Report

Yonts, W. L., 1971, Low-flow measurements of North Carolina streams: North Carolina Department of Water and Air Resources.
}

\section{Interpretive Reports}

Arteaga, F. E., and Hubbard, E. F., 1974, Evaluation of reservoir sites in North Carolina: U. S. Geological Survey Water-Resources Investigations 46-74.

Coble, R. W., 1979, A technique for estimating heights reached by the 100 -year flood on unregulated, nontidal streams in North Carolina: U. S. Geological Survey Water-Resources Investigations 79-69. 
Interpretive Reports, Continued

Daniel, C. C., III, 1977, Digital flow model of the CHOWAN RIVER ESTUARY, North Carolina: U. S. Geological Survey Water-Resources Investigations 77-63.

Eddins, W. H., and Jackson, N. M., Jr., 1980, A technique for estimating flood heights on small streams in the CITY OF CHARLOTTE and MECKLENBURG COUNTY, North Carolina: U. S. Geological Survey Water-Resources Investigations 80-106.

Giese, G. L., 1976, Thermal loading of HYCO LAKE, North Carolina--The effect of heated water on temperature and evaporation, 1966-74: U. S. Geological Survey WaterResources Investigations 76-48.

Giese, G. L., Wilder, H. B., and Parker, G. G., Jr., 1985, Hydrology of MAJOR ESTUARIES AND SOUNDS of North

Carol ina: U. S. Geological Survey Water-Supply Paper 2221.

Goddard, G. C., Jr., 1963, Water-supply characteristics of North Carolina streams: U. S. Geological Survey WaterSupply Paper 1761.

Goddard, G. C., Jr., Jackson, N. M., Jr., Hubbard, E. F., and Hinson, H. G., 1970, A proposed streamflow data program for North Carolina: U. S. Geological Survey Open-File Report.

Haire, W. J., 1968, Floods on Boone and Winkler Creeks at BOONE, North Carolina: U. S. Geological Survey Hydrologic Investigations Atlas HA-323.

1968, Floods on Little Buffalo Creek at WEST JEFFERSON, North Carolina: U. S. Geological Survey Hydrologic Investigations Atlas HA-331.

Heath, Ralph C., 1978, Floods and droughts; The worst are yet to be: North Carolina Water Resources Research Institute (brochure).

Hinson, H. G., 1965, Floods on small streams in North Carolina --Probable magnitude and frequency: U. S. Geological Survey Circular 517.

Hubbard, E. F., and Stamper, W. G., 1972, Movement and dispersion of soluble pollutants in the NORTHEAST CAPE FEAR ESTUARY, North Carolina: U. S. Geological Survey Water-Supply Paper 1873-E. 
Jackson, N. M., Jr., 1968, Flow of the CHOWAN RIVER, North Carolina--A study of the hydrology of an estuary affected primarily by winds: U. S. Geological Survey Open-File Report.

1976, Magnitude and frequency of floods in North Carolina: U. S. Geological Survey Water-Resources Investigations 76-17.

Lindskov, K. L., 1974, Movement and dispersion of soluble materials in Salem Creek, Muddy Creek, and Yadkin River between WINSTON-SALEM and SALISBURY, North Carolina:

U. S. Geological Survey Water-Resources Investigations 6-74.

Martens, L. A., 1968, Flood inundation and effects of urbanization in METROPOLITAN CHARLOTTE, North Carolina: U. S. Geological Survey Water-Supply Paper 1591-C.

Mason, R. R., and Jackson, N. M., Jr., 1985, Cost-effectiveness of the stream-gaging program in North Carolina: U. S. Geological Survey Water-Resources Investigations Report 85-4036.

Putnam, A. L., 1972, Effects of urban development on floods in the PIEDMONT PROVINCE of North Carolina: U. S. Geological Survey Open-File Report.

Simmons, C. E., and Aldridge, M. C., 1980, Hydrology of the CHICOD CREEK BASIN, North Carol ina, prior to channel improvements: U. S. Geological Survey Open-File Report 80-680.

Stamey, T. C., 1986, Frequency and duration of flooding of Grove Creek near KENANSVILLE, North Carolina, for present and proposed restored channel conditions: U. S. Geological Survey Water-Resources Investigations Report 85-4298.

Stamper, W. G., 1975, Flood mapping in CHARLOTTE and MECKLENBURG COUNTY, North Carolina: U. S. Geological Survey Open-File Report.

Stewart, J. M., Heath, R. C., and Morris, J. N., 1978, Floods in WESTERN NORTH CAROLINA, November 1977, A lesson for the future: North Carolina Water Resources Research Institute.

Thomas, N. O., and Bonham, W. G., 1977, Annual maximum stages and discharges of North Carol ina streams: U. S.

Geological Survey Open-File Report 77-367. 


\section{Interpretive Reports, Continued}

Turner, J. F., Jr., 1966, Evaporation study in a humid region, LAKE MICHIE, North Carolina: U. S. Geological Survey Professional Paper 272-G.

Watkins, S. A., and Simmons, C. E., 1984, Hydrologic conditions in the CHICOD CREEK BASIN, North Carol ina, before and during channel modifications, 1975-81: U.S. Geological Survey Water-Resources Investigations Report 84-4025, $36 \mathrm{p}$.

Yonts, W. L., Giese, G. L., and Hubbard, E. F., 1973, Evaporation from LAKE MICHIE, North Carol ina, 1961-71: U. S. Geological Survey Water-Resources Investigations 38-73.

Yonts, W. L., and Giese, G. L., 1974, The effect of heated water on the temperature and evaporation of HYCO LAKE, North Carolina, 1966-72: U. S. Geological Survey WaterResources Investigations 11-74.

\section{Quality of Water}

Data Reports

Data on the quality of surface water are given in the watersupply paper (WSP) series of the U. S. Geological Survey, "Quality of Surface Waters of the United States," which is also released annually in numbered parts as determined by natural drainage basins. Data for North Carolina before 1959 are in volumes numbered Parts 1-4 and thereafter in volumes numbered Parts 1-2 and Parts 3-4. From the 1964 water year (October 1963-September 1964) through the 1974 water year, these data have also been released annually in a single open-file report covering the entire State. As of 1975, quality of water data are released in the annual publication, "Water Resources Data for North Carolina, Water Year _." Additional basic-data reports pertaining to water quality are listed below:

Knobel, L. L., 1985, Ground-water-quality data for the ATLANTIC COASTAL PLAIN: New Jersey, Delaware, Maryland, Virginia and North Carolina: U. S. Geological Survey Open-File Report 85-154.

North Carolina Department of Conservation and Development 1947-56, Chemical and physical character of surface water of North Carolina: North Carolina Department of Conservation and Development Bullet in 52, v. 1, (194445); v. 2, (1945-56); v. 3, (1946-47); v. 4, (1947-48); v. $5,(1948-49)$; v. 6 , $(1949-50)$; v. 7, $(1950-51)$; v. 8, (1951-52); v. 9, (1952-53); v. 10, $(1953-54)$; v. 11, (1954-55); v. 12, (1955-56). 
Data Reports, Continued

North Carolina Department of Water Resources, Division of Stream Sanitation and Hydrology, 1956-67, Chemical and physical character of surface waters of North Carolina: North Carolina Department of Water Resources Bulletin 1, v. I, (1956-57); v. II, (1957-58); v. III, (1958-59);

v. IV, $(1959-60)$; v. V, (1960-61); v. VI, (1961-62);

v. VII, (1962-63); V. VIII, (1963-64); V. IX, (1964-65);

v. $X,(1965-66)$.

North Carolina Department of Water Resources, Division of Stream Sanitation and Hydrology, 1961-69, Chemical and physical character of municipal water supplies in North Carolina: North Carolina Department of Water Resources Bulletin 2 (1961); Bulletin 2, supp. 1 (1962); Bulletin 2, supp. 2 (1964); Bulletin 2, supp. 3 (1965); Bulletin 3 (1969).

U. S. Geological Survey, 1964-74, Water-resources data for North Carolina--Part 2, Water-quality records.

1975-80, Water-resources data for North Carolina--Water NC $-{ }_{\text {N______ }}$ : U. S. Geological Survey Water-Data Report

Wilder, H. B., and S1ack, L. J., 1971, Summary of data on chemical quality of streams of North Carolina, 1943-67:

U. S. Geological Survey Water-Supply Paper 1895-B.

Woodard, T. H., 1970, Summary of data on temperature of streams in North Carolina, 1943-67: U. S. Geological Survey Water-Supply Paper 1895-A.

\section{Interpretive Reports}

Berry, E. L., 1970, Ground-water qual ity in STANLY COUNTY, North Carolina: North Carolina Department of Water and Air Resources Ground-Water Circular 15.

Crawford, J. Kent, 1985, Water-quality characteristics for selected sites on the CAPE FEAR RIVER, North Carolina, 1955-80, variability, loads, and trends of selected constituents: U. S. Geological Survey Professional Paper 2185-F.

Daniel, C. C., III, Wilder, H. B., and Weiner, M. S., 1982, Water Quality of the FRENCH BROAD RIVER, North Carolina, An analysis of data collected at Marsha11, 1958-77:

U. S. Geological Survey Professional Paper 2185-C. 


\section{Interpretive Reports, Continued}

Eddins, W. H., and Crawford, J. K., 1984, Reconnaissance of water-quality characteristics of streams in the CITY

OF CHARLOTTE and MECKLENBURG COUNTY, North Carolina:

U. S. Geological Survey Water-Resources Investigations Report 84-4308.

Harned, D. A., 1982, Water quality of the NEUSE RIVER, North Carolina, Variability, pollution loads, and long-term trends: U. S. Geological Survey Professional Paper 2185-D.

Harned, D. A., Danie1, C. C., III, and Crawford, J. K., 1981, Methods of discharge compensation as an aid to the evaluation of water quality trends: Water Resources Research, v. 17, no. 5, p. 1389-1400.

Harned, D. A., and Meyer D., 1983, Water quality of the YADKIN-PEE DEE RIVER system, North Carolina--Variability, pollution loads, and long-term trends: U. S. Geological Survey Professional Paper 2185-E.

LeGrand, H. E., 1958, Chemical character of water in the igneous and metamorphic rocks of North Carolina:

Economic Geology, v. 53, no. 2, p. 178-189.

Reeder, H. E., 1970, Sedimentation in THIRD CREEK SUBWATERSHED NO. 7A, North Carolina: U. S. Geological Survey Open-File Report.

1973, Sediment resulting from construction of an interstate highway in the PIEDMONT AREA of North Carolina: U. S. Geological Survey Open-File Report.

Simmons, C. E., 1975, Sediment characteristics of streams in EASTERN PIEDMONT and WESTERN COASTAL PLAIN regions of North Carolina: U. S. Geological Survey Water-Supply Paper 1798-0.

Simmons, C. E., 1980, Quality of water in the BLACK RIVER NEAR DUNN, North Carolina, and ground-water levels adjacent to the river prior to channel excavation in 1976-79:

U. S. Geological Survey Open-File Report 80-425.

Simmons, C. E., and Heath, R. L., 1982, Water-quality characteristics of streams in forested and rural areas of North Carolina: U. S. Geological Survey Professional Paper 2185-B. 
Interpretive Reports, Continued

Simmons, C. E., and Watkins, S. A., 1982, The effects of channel excavation on water-quality characteristics of the BLACK RIVER and on ground-water levels NEAR DUNN, North Carolina: U. S. Geological Survey Water-Resources Investigations Report 82-4083.

Wilder, H. B., 1972, Investigation of the occurrences and transport of arsenic in the UPPER SUGAR CREEK WATERSHED, CHARLOTTE, North Carolina: U. S. Geological Survey Professional Paper 800-D, p. 205-210.

Wilder, H. B., and Hubbard, E. F., 1968, Sea-water encroachment in the CAPE FEAR RIVER ESTUARY, North Carolina:

U. S. Geological Survey Open-File Report.

Wilder, H. B., and Slack, L. J., 1971, Chemical quality of water in streams of North Carolina: U. S. Geological Survey Hydrologic Investigations Atlas HA-439.

Wilder, H. B., and Simmons, C. E., 1982, Program for evaluating stream quality in North Carolina: U. S. Geologica1 Survey Professional Paper 2185-A.

Ground Water

Data Reports

Prior to 1975, ground-water levels and artesian pressures in observation wells were published in the Water-Supply Papers (WSP) listed in the following table. Since 1975, publication has been in the annual water-data report series which are distributed each year by the District office in Raleigh.

\begin{tabular}{rrrrrrrr}
\hline Year & WSP & Year & WSP & Year & WSP & Year & WSP \\
\hline 1935 & 777 & 1942 & 945 & 1949 & 1157 & $1956-58$ & 1538 \\
1936 & 817 & 1943 & 987 & 1950 & 1166 & $1959-63$ & 1803 \\
1937 & 840 & 1944 & 1017 & 1951 & 1192 & $1964-68$ & 1978 \\
1938 & 845 & 1945 & 1024 & 1952 & 1222 & $1969-73$ & 2171 \\
1939 & 886 & 1946 & 1072 & 1953 & 1266 & & \\
1940 & 907 & 1947 & 1097 & 1954 & 1322 & & \\
1941 & 937 & 1948 & 1127 & 1955 & 1405 & & \\
\hline
\end{tabular}


Data Reports, Continued

U. S. Geological Survey, Water-Resources Data for North Carolina--Water Year 19_: U. S. Geological Survey Water-Data Report NC-1 .

\section{Interpretive Reports}

Bain, G. L., 1966, Geology and ground-water resources of the DURHAM AREA, North Carolina: North Carolina Department of Water Resources Ground-Water Bulletin 7.

1970, Geology and ground-water resources of NEW HANOVER COUNTY, North Carolina: North Carolina Department of Water and Air Resources Ground-Water Bullet in 17.

BTankenship, R. R., 1965, Reconnaissance of ground-water resources of the SOUTHPORT-ELIZABETHTOWN AREA, North Carolina: North Carolina Department of Water Resources Ground-Water Bullet in 6.

Brown, P. M., 1958, Well logs from the COASTAL PLAIN of North Carolina: North Carolina Department of Conservation and Development Bulletin 72 .

1959, Geology and ground-water resources in the GREENVILLE AREA, North Carolina: North Carolina Dapartment of Conservation and Development Bulletin 73.

Brown, P. M., 1960, Ground-water supply of CAPE HATTERAS National Seashore Recreational area: North Carolina Department of Water-Resources Report Investigations 1.

Brown, P. M., Miller, J. A., and Swain, F. M., 1972, Structural and stratigraphic framework and spatial distribution of the permeability of the ATLANTIC COASTAL PLAIN, New York to North Carolina: U. S. Geological Survey Professional Paper 796.

Daniel, C. C., III, and Sharpless, N. B., 1983, Ground-water supply potential and precedures for well-site selection in the UPPER CAPE FEAR RIVER BASIN, North Carolina: North Carolina Department of Natural Resources and Community Development, $73 \mathrm{p}$.

DeWiest, R. J. M., Sayre, A. N., and Jacob, C. E., 1967, Evaluation of potential impact of phosphate mining on ground-water resources of eastern North Carolina: North Carolina Department of Water Resources. 


\section{Interpretive Reports, Continued}

Dodson, C. L., and Laney, R. L., 1968, Geology and groundwater resources of the MURPHY AREA, North Carolina: North Carolina Department of Water and Air Resources Ground-Water Bulletin 13.

Duncan, D. A., and Peace, R. R., 1966, Ground-water resources of CLEVELAND COUNTY, North Carol ina: North Carolina Department of Water Resources Ground-Water Bulletin 11.

Floyd, E. 0., 1965, Geology and ground-water resources of the MONROE AREA, North Carolina: North Carolina Department of Water Resources Ground-Water Bulletin 5.

1969, Ground-water resources of CRAVEN COUNTY, North Carolina: U. S. Geological Survey Hydrologic Investigations Atlas HA-343.

Floyd, E. O., and Long, A. T., 1970, Well records and other basic ground-water data, CRAVEN COUNTY, North Carolina: North Carolina Department of Water and Air Resources Ground-Water Circular 14.

Floyd, E. O., and Peace, R. R., 1974, An appraisal of the ground-water resources of the UPPER CAPE FEAR RIVER BASIN, North Carolina: North Carolina Department of Water and Air Resources Ground-Water Bulletin No. 20.

Groves, M. R., 1976, Preliminary report on ground-water resources of ROWAN COUNTY, North Carol ina: North Carolina Department of Natural and Economic Resources Ground-Water Bulletin 22.

Harris, W. H., and Wilder, H. B., 1964, Ground-water supply of CAPE HATTERAS National Seashore Recreational Area, North Carolina--Part 3: North Carolina Department of Water Resources Report of Investigations 4.

1966, Geology and ground-water resources of the HERTFORDELIZABETH CITY AREA, North Carol ina: North Carolina Department of Water Resources Ground-Water Bulletin 10.

Heath, R. C., 1980, Basic elements of ground-water hydrology with reference to conditions in North Carolina: U. S. Geological Survey Water-Resources Investigations OpenFile Report 80-44.

Heath, R. C., and Giese, G. L., 1980, What about ground water in the PIEDMONT AND MOUNTAINS of North Carolina--Are large supplies feasible?: U. S. Geological Survey brochure. 
Interpretive Reports, Continued

Kimrey, J. 0., 1960, Ground-water supply of CAPE HATTERAS National Seashore Recreational Area, North Carolina-Part 2: North Carolina Department of Water Resources Report of Investigations 2 .

1961, Ground-water supply for the DARE BEACHES Sanitary District, North Carolina: North Carolina Department of Water Resources Report of Investigations 3.

Laymon, L. L., and Barksdale, R. G., 1964, Ground-water conditions in the CLINTON AREA, North Carolina: North Carolina Department of Water Resources Ground-Water Circular 3.

LeGrand, H. E., 1954, Geology and ground water in the STATESVILLE AREA, North Carolina: North Carolina Department of Conservation and Development Bulletin 68.

1956, Ground-water resources in North Carolina: North Carolina Department of Conservation and Development Bulletin 69.

1960, Geology and ground-water resources of the WILMINGTON-NEW BERN AREA: North Carol ina Department of Water Resources Ground-Water Bulletin 1.

1967, Ground water of the PIEDMONT AND BLUE RIDGE PROVINCES in the southeastern states: U. S. Geological Survey Circular 538.

LeGrand, H. E., and Mundorff, M. J., 1952, Geology and ground water in the CHARLOTTE AREA, North Carolina: North Carolina Department of Conservation and Development Bulletin 63 .

Lloyd, 0. B., Jr., 1968, Ground-water resources of CHOWAN COUNTY, North Carolina: U. S. Geological Survey Hydrologic Investigations Atlas HA-292.

1968, Ground-water resources of CHOWAN COUNTY, North Carolina: North Carolina Department of Water and Air Resources Ground-Water Bulletin 14.

Lloyd, O. B., Jr., and Dean, R. B., 1968, Ground-water supply of CAPE HATTERAS National Seashore Recreational Area, North Carolina--Part 6: North Carolina Department of Water and Air Resources Report of Investigations 7. 
Lloyd, O. B., Jr., and Floyd, E. 0., 1968, Ground-water resources of the BELHAVEN AREA, North Carolina: North Carolina Department of Water and Air Resources Report of Investigations 8.

Lloyd, O. B., Jr., Larson, J. D., and Davis, R. W., 1985, Summary of northern Atlantic Coastal Plain hydrology and its relation to disposal of high-level radioactive waste in buried crystalline rock, a preliminary appraisal: U.S. Geological Survey Water-Resources Investigations Report 85-4146.

Lloyd, O. B., Jr., and Wilder, H. B., 1968, Ground-water supply of CAPE HATTERAS National Seashore Recreational Area, North Carolina--Part 4: North Carol ina Department of Water and Air Resources Report of Investigations 5.

Lohman, S. W., 1936, Geology and ground-water resources of ELIZABETH CITY AREA, North Carol ina: U. S. Geological Survey Water-Supply Paper 773-A.

Marsh, 0. T., and Laney, R. L., 1966, Reconnaissance of the ground-water resources in the WAYNESVILLE AREA, North Carolina: North Carolina Department of Water Resources Ground-Water Bulletin 8.

May, V. J., and Thomas, J. D., 1968, Geology and ground-water resources in the RALEIGH AREA, North Carolina: North Carolina Department of Water and Air Resources GroundWater Bulletin 15.

Mundorff, M. J., 1946, Ground water in the HALIFAX AREA, North Carolina: North Carolina Department of Conservation and Development Bulletin 51.

1948, Ground water in the GREENSBORO AREA, North Carolina: North Carolina Department of Conservation and Development Bulletin 55.

1950, Flood-plain deposits of North Carolina PIEDMONT AND MOUNTAIN STREAMS as a possible source of ground-water supply: North Carolina Department of Conservation and Development Bullet in 59.

Nelson, P. F., 1964, Geology and ground-water resources of the SWANQUARTER AREA: North Carol ina Department of Water Resources Ground-Water Bullet in 4. 
Interpretive Reports, Continued

Nelson, P. F., and Barksdale, R. G., 1965, Interim report on the ground-water resources of the KINSTON AREA, North Carolina: North Carolina Department of Water Resources Ground-Water Circular 10.

Peace, R. R., Jr., and Link, D. R., 1971, Geology and groundwater resources of NORTHWESTERN NORTH CAROLINA: North Carolina Department of Water and Air Resources GroundWater Bulletin 19.

Pusey, R. D., 1960, Geology and ground water in the GOLDSBORO AREA, North Carolina: North Carolina Department of Water Resources Ground-Water Bulletin 2.

Schipf, R. G., 1961, Geology and ground-water resources of the FAYETTEVILLE AREA: North Carolina Department of Water Resources Ground-Water Bulletin 3.

Sumsion, C. T., 1968, Summary of the geology and ground-water resources of PITT COUNTY, North Carol ina: U. S. Geological Survey Hydrologic Investigations Atlas HA-291.

1970, Geology and ground-water resources of PITT COUNTY, North Carolina: North Carolina Department of Water and Air Resources Ground-Water Bulletin 18.

Sumsion, C. T., and Laney, R. L., 1967, Geology and groundwater resources of the MORGANTON AREA, North Carolina Department of Water Resources Ground-Water Bullet in 12.

Trapp, Henry, Jr., 1970, Geology and ground-water resources of the ASHEVILLE AREA, North Carolina: North Carol ina Department of Water and Air Resources Ground-Water Bulletin 16.

Winner. M. D., Jr., 1975, Ground-water resources of the CAPE HATTERAS National Seashore, North Carolina: U. S. Geological Survey Hydrologic Investigations At1as HA-540.

1976, Ground-water resources of WILSON COUNTY, North Carolina: U. S. Geological Survey Water-Resources Investigations 76-60.

1977, Ground-water resources along the BLUE RIDGE PARKWAY, North Carolina: U. S. Geological Survey WaterResources Investigations 77-65.

1978, Ground-water resources of the CAPE LOOKOUT NATIONAL SEASHORE, North Carolina: U. S. Geological Survey WaterResources Investigations 78-52. 
Interpretive Reports, Continued

Winner, M. D., 1981, An observation-well network concept as applied to North Carolina: U. S. Geological Survey Water-Resources Investigations 81-13.

1981, Proposed observation-well networks and groundwater level program for North Carolina: U. S. Geological Survey Open-File Report 81-544.

Wyrick, G. G., 1966, Ground-water resources of MARTIN COUNTY, North Carolina: North Carolina Department of Water Resources Ground-Water Bulletin 9.

1967, Water-bearing characteristics and occurrence of aquifers in MARTIN COUNTY, North Carolina: U. S. Geological Survey Hydrologic Investigations Atlas HA-264.

Wyrick, G. G., and Dean, R. B., 1968, Ground-water supply of CAPE HATTERAS National Seashore Recreational Area, North Carolina--Part 5: North Carolina Department of Water and Air Resources Report of Investigations 6.

\section{Water-Resources Reports}

Billingsley, G. A., Fish, R. E., and Schipf, R. G., 1957, Water resources of the NEUSE RIVER BASIN, North Carolina: U. S. Geological Survey Water-Supply Paper 1414.

Daniel, C. C., III, 1978, Land use, land cover, and drainage on the ALBEMARLE-PAMLICO PENINSULA, eastern North Carolina, 1974: U. S. Geological Survey Water-Resources Investigations 78-134.

1981, Hydrology, geology and soils of pocosins: A comparison of natural and altered systems, in Richardson, C. J., ed., Pocosin wetlands: An integrated analys is of COASTAL PLAIN freshwater bogs in North Carolina:

Stroudsburg, Hutchinson, and Ross, Inc., p. 69-108.

Fish, R. E., LeGrand, H. E., and Billingsley, G. A., 1957, Water resources of the YADKIN-PEE DEE RIVER BASIN, North Carolina: U. S. Geological Survey Water-Supply Paper 1415.

Heath, R. C., 1975, Hydrology of the ALBEMARLE-PAMLICO REGION, North Carolina: U. S. Geological Survey Water-Resources Investigations 9-75. 


\section{Water-Resources Reports, Continued}

Heath, R. C., Thomas, N. 0., and Duback, Harold, 1975, North Carolina Atlas--Chap. 8, Water Resources: University of North Carolina Press.

Jackson, N. M., Jr., 1972, Public water supplies of North Carolina--Part 1, NORTHERN PIEDMONT: North Carolina Department of Natural and Economic Resources, 277 p.

1973, Public water supplies of North Carolina--Part 2, SOUTHERN PIEDMONT: North Carolina Department of Natural and Economic Resources, $255 \mathrm{p}$.

1974, Public water supplies of North Carolina--Part 3, MOUNTAINS AND WESTERN PIEDMONT: North Carolina Department of Natural and Economic Resources, 232 p.

Lindskov, K. L., 1973, Water resources of NORTHEAST NORTH CAROLINA above Cape Lookout--Interim report: U. S. Geological Survey Open-File Report.

Mann, L. T., Jr., 1978, Public water supplies of North Carolina, A summary of water sources, use, treatment, and capacity of water-supply systems: U. S. Geological Survey Water-Resources Investigations 78-16.

McMaster, W. M., and Hubbard, E. F., 1970, Water resources of the GREAT SMOKEY MOUNTAINS NATIONAL PARK, Tennessee and North Carolina: U. S. Geological Survey Hydrologic Investigations Atlas HA-420.

Putnam, A. L., and Lindskov, K. L., 1973, Water resources of the UPPER NEUSE RIVER BASIN, North Carolina: U. S. Geological Survey Water-Resources Investigations 12-73.

Robison, T. M., 1977, Public water supplies of North Carolina, Part 4, NORTHERN COASTAL PLAIN: North Carolina Department of Natural and Economic Resources, $218 \mathrm{p}$.

Robison, T. M., and Mann, L. T., Jr., 1977, Public water supplies of North Carolina--Part 5, SOUTHERN COASTAL PLAIN: North Carolina Department of Natural and Economic Resources, $333 \mathrm{p}$.

U. S. Geological Survey, 1975, Hydrologic unit map of North Carolina--1974.

Wilder, H. B., Robinson, T. M., and Lindskov, K. L., 1978, Water resources of NORTHEAST NORTH CAROLINA: U. S. Geological Survey Water-Resources Investigations 77-81.

Winner, M. D., Jr., and Simmons, C. E., 1977, Hydrology of the CREEPING SWAMP WATERSHED, North Carolina, with reference to potential effects of stream channelization: U. S. Geological Survey Water-Resources Investigations 77-26. 